\title{
Genetic resistance of wheat towards plant-parasitic nematodes: current status and future prospects
}

\author{
Awol Seid ${ }^{1}\left(\mathbb{D}\right.$, Mustafa İmren ${ }^{2}$, Muhammad Amjad Ali $^{3}{ }^{(\mathbb{D}}$, Fateh Toumi $^{4}{ }^{(\mathbb{D}}$, \\ Timothy Paulitz ${ }^{5}$, Abdelfattah A. Dababat ${ }^{6 *}$
}

${ }^{1}$ Plant Protection Program, School of Plant Sciences, College of Agriculture and Environmental Sciences, Haramaya University, POBOX 138, Dire Dawa, Ethiopia.

${ }^{2}$ Department of Plant Protection, Faculty of Agriculture and Natural Science, Bolu Abant İzzet Baysal University, Gölköy 14300, Bolu, Turkey.

${ }^{3}$ Department of Plant Pathology, University of Agriculture, Punjab 38000, Faisalabad, Pakistan.

${ }^{4}$ Plant Protection Department, Agriculture Directorate, Ministry of Agriculture, 9051415, Hama, Syria.

${ }^{5}$ United States Department of Agriculture, Agricultural Research Service, Wheat Health, Genetics and Quality Research Unit, Washington State University, WA 99164-6430, Pullman, USA.

${ }^{6}$ CIMMYT -Turkey, P.K. 39 Emek 06511, Ankara, Turkey.

\section{How to Cite}

Seid, A., İmren, M., Amjad Ali, M., Toumi, F., Paulitz, T., \& Dababat, A. A. (2021). Genetic Resistance of Wheat Towards Plant-Parasitic Nematodes: Current Status and Future Prospects. Biotech Studies, 30(1), 43-62. https://doi.org/10.38042/biotechstudies.944678

\begin{abstract}
Plant-parasitic nematodes (PPNs) are one of the major biotic factors that cause significant yield losses in wheat-growing areas worldwide. The major PPN groups causing significant economic losses in wheat quantity and quality are cereal cyst nematodes (CCNs) and root-lesion nematodes (RLNs). Based on their wide distribution, pathogenicity, high occurrence in wheat cultivated areas, they are considered major threats to the global food supply. The economic loss caused by these destructive pathogens ranges from 10 to $100 \%$ depending on different agro-ecological conditions such as drought, heat stress, and cold stress. Multidisciplinary management practices are being implemented to manage cereal nematodes (CNs) that range from cultural to molecular strategies. Integration of wheat resistant varieties with appropriate agronomic practices is recognized as the safest and most practical, effective, and applicable management strategy. Nine resistance genes (Cre1-Cre9) to $\mathrm{CCN}$ are well-documented in the literature. CreR, $\mathrm{CreV}$ and $\mathrm{CreZ}$ genes are relatively recently characterized from wheat and confer resistance to CCNs. On the other hand, RInn1 is the only resistance gene characterized from wheat that is known to confer resistance towards RLNs. However, breeding for resistance to PPN has numerous challenges that originate from the narrow genetic diversity and difficulty in the process of transferring resistance gene(s) from the source to the target variety. A unique opportunity for wheat genetic improvement was provided due to the availability of genomic resources and the wheat worldwide germplasm collection which includes wild wheat germplasm. Moreover, the presence of several genome-wide association studies and genome editing technologies could also help for further improvement to enhance $\mathrm{CN}$ s resistance in wheat. This article provides the latest information regarding the progress made in the identification and characterization of resistance genes from different sources and its utility against both CCNs and RLNs, which will attract the attention of the scientific community and other relevant stakeholders.
\end{abstract}

\section{Introduction}

Wheat is a cereal grain and global staple food. Bread wheat (Triticum aestivum L.) is an allohexaploid ( 17 Gbp genome size) derived from a combination of three closely related genomes $(A, B$, and $D)$ formed through multiple hybridizations among these three diverse ancestor species (Feldman et al., 2012). The earliest hybridization happened between $T$. urartu (AA, $2 n=14$ ) as the $A$-genome donor and an unknown species 
with the B-genome (BB, $2 \mathrm{n}=14$, presumably Aegilops speltoides) (McFadden \& Sears, 1946), resulting in the tetraploid ancestor of modern Triticum species, wild emmer wheat $T$. turgidum ssp. Dicoccoides (AABB, $2 n=28$ ), this further hybridized with $A$. tauschii (DD, $2 n=14$ ) ending with the modern bread wheat (AABBDD, $2 n=42$ ) (Huang et al., 2002; Dubcovsky \& Dvorak, 2007; Hussain \& Rivandi, 2007; Shewry, 2009; Matsuoka, 2011). Wheat is considered among the most ancient of cultivated cereal crops originating in the Fertile Crescent around 9,600 B.C (Piperno et al., 2004). Based on the FAOSTAT (2019 data, bread wheat is grown on over 215 million hectares of land globally, which is feeding over $40 \%$ of the global population (Taheri et al., 2019) contributing approximately to up to $30 \%$ of the total world food grain production (FAOSTAT, 2019). It is the main food crop used worldwide and contains the major source of proteins (21\%) and calories (19\%) in human diets, and provides substantial feed to animals (Shiferaw et al., 2013) compared with other food crops. Due to its high yielding, nutrition value, ease of grain storage, and transformation into wide varieties of food forms, wheat is a vital diet component (Curtis, 2002; Shewry, 2009). Moreover, it provides essential amino acids, minerals, vitamins and dietary fiber (Shewry, 2009; Bockus et al., 2010).

Globally, wheat production needs to be enlarged by $60 \%$ to achieve the projected demand by 2050 (Ackerman \& Stanton, 2008). World wheat production is boosted mainly due to the wider usage of agricultural technologies and the deployment of improved cultivars and farming practices (Shiferaw et al., 2013). However, wheat production is still limited by both biotic (diseases, nematodes, insect pests, weeds, etc.) and abiotic (adverse climatic, salinity, and edaphic) constraints (Husenov et al., 2020). Among these production limitations, plant-parasitic nematodes (PPNs) were estimated to decrease production by $10 \%$ (Whitehead, 1998). Among the PPNs recorded on wheat, CCN and RLN are the major ones, are among the top ten economically important genera (Jones et al., 2013), and were ranked $2^{\text {nd }}$ and $3^{\text {rd }}$ in their economically and scientifically important after the root-knot nematode genera (Dababat \& Fourie, 2018). Cereal cyst nematodes (Heterodera spp.) (CCNs) have a wide distribution and cause a considerable yield loss in many countries (Hajihassani et al., 2010; Dababat et al., 2015; Pariyar et al., 2016a; Toumi et al., 2017; Renco et al., 2018). The major species of CCN affecting cereal crops including wheat are Heterodera avenae, $H$. filipjevi and $H$. latipons (Imren et al., 2013; Toumi et al., 2013; Baklawa et al., 2015; Imren et al., 2019). The major root-lesion nematodes (Pratylenchus spp.) (RLN) species are Pratylenchus thornei, $P$. neglectus, $P$. penetrans, and $P$. crenatus where all above-mentioned species have a global distribution and sometimes co-exist in a single field (Nicol et al., 2003; Smiley \& Nicol, 2009; Dababat et al., 2016). Apart from the CCN and RLN damage on wheat crops individually they are also known to interact with each other as well as with other soil-borne fungal pathogens such as the crown rot fungus (Fusarium culmorum), which is known to limit wheat yield in temperate and semi-tropical regions of the world, creating a disease complex (Hajihassani et al., 2013; Dababat et al., 2018).

The efficient management of wheat crop diseases is crucial in maintaining world food supply stability (Ogbonnaya et al., 2008). The wheat crop can be protected from $\mathrm{CN}$ damage by various management strategies such as crop rotation, host resistance, cultural practice, biological control, and application of chemicals mainly nematicides (Dababat et al., 2015). The genetic differences in landraces and domesticated wheat cultivars offered resistance against a considerable number of abiotic and biotic stresses (Pariyar et al., 2016b). Integrating resistance genes into breeding resistant lines and wheat cultivars are considered the most fruitful management strategy to lower nematode populations below the economic threshold level (Dababat et al., 2015). Resistance management is an ecologically and friendly approach and achievable through the international active partnership of research groups (Smiley et al., 2011; Smiley \& Marshall, 2016). Therefore, this review article provides the latest information about the distribution and economic importance of main CNs on wheat, and the progress made in the identification and characterization of resistance genes from different sources and its utility against CCN and RLN, which will attract the attention of the scientific community and other relevant stakeholders.

\section{Major Plant-Parasitic Nematodes of Wheat}

Over 4100 species of PPNs have been characterized and documented (Decraemer \& Hunt, 2006). PPNs are known to cause extensive damage to many plant species including wheat (Chen et al., 2017). Collectively, they cause annual estimated damage of $\$ 80-118$ billion dollars to crops (Nicol et al., 2011). CCN attack wheat crop and cause significant damage in its production. Their damage is also documented on other cereal crops including barley (Hordeum vulgare) and oat (Avena sativa) (Amjad et al., 2019). In some wheat cultivating states of the USA (Idaho, Oregon, and Washington) an estimated 3.4 US\$ million are lost annually (Smiley \& Guiping, 2010). The yield losses caused by $H$. avenae in some wheat-growing fields could be in the range of 30 to $100 \%$ (Ibrahim et al., 1999; Nicol et al., 2004). Root-lesion nematodes are documented to cause in the range of 10 to $85 \%$ yield loss on wheat crop (Nicol \& Rivoal, 2008; Smiley, 2010). Also, other losses of wheat are caused by the seed gall nematode (Anguina tritici), stem and bulb nematode (Ditylenchus dipsaci) (Tulek et al., 2015) and root-knot nematodes (Meloidogyne spp.) (Seid et al., 2015). 


\section{Distribution of Wheat Nematodes}

\section{Cereal cyst nematodes (CCNs)}

The genus Heterodera is considered to be one of the oldest identified genera of PPN. In 1859, Schacht reported the first cyst-forming nematode on roots of sugar beet. Later, Schmidt erected Heterodera at the genus level and described it as $H$. schachtii in 1871 (Schmidt, 1871). Cyst nematodes parasitizing cereal crops were also reported in 1874 by Kühn in Germany. A species of the genus Heterodera parasitizing peas but differing from $\mathrm{H}$. schachtii because it did not damage oats, hence, it was reported and named as $H$. goettingiana (Liebscher, 1892). With the documentation and recognition of the host-specificity of the nematode's cyst forming, more cyst nematode species could be identified and characterized. Heterodera rostochiensis which is one of the potato cyst nematode species was described from potatoes (Wollenweber, 1923), and $H$. avenae (oat cyst nematode) was reported from cereals (Wollenweber, 1924). Afterward, several nematodes forming cysts were detected on cereals and subsequently reported. These CCNs form a complex of numerous closely related species with a recognised global distribution on Poaceae family (Nicol et al., 2004; Nicol \& Rivoal, 2008). Heterodera avenae was the first reported (Kühn, 1874), and then, the Mediterranean $H$. latipons (Franklin, 1969), followed by the north European H. hordecalis (Andersson, 1974), the eastern European H. filipjevi (Madzhidov, 1981), and others (Wouts et al., 1995). The cyst forming genus Heterodera contains 70 species including $H$. avenae group which is a complex of 12 known species and parasitizes cereals and grasses (McDonald \& Nicol, 2005). However, H. avenae, $H$. filipjevi and $H$. latipons are considered the most economically important species in cereals worldwide (Nicol et al., 2007b) and each will be discussed briefly as follows.

\section{Heterodera avenae}

Heterodera avenae is an important species with global extensive distribution (Wen et al., 2019). It has a wide distribution in wheat-growing regions across Europe, Asia, Australia, the Mediterranean, South Africa, and North and South America (Smiley et al., 2017).

\section{Heterodera latipons (Mediterranean cereal cyst} $\underline{\text { nematode) }}$

Heterodera latipons has been recorded from the Mediterranean region, Europe, Asia, and North Africa, but not in the USA (Smiley et al., 2017). This species has an extensive distribution and mainly in the Mediterranean region like Syria (Sikora \& Oostendorp, 1986), Jordan (Yousef \& Jacob, 1994), Lebanon (Greco et al., 2002) and Turkey (Rumpenhorst et al., 1996). Moreover, this species was found to be present in temperate climates of the former USSR (Subbotin et al., 1996), Iran (Tanha Maafi et al., 2007), and Europe: Czech Republic (Sabova et al., 1988), Bulgaria (Stoyanov,
1982), and United Kingdom (Anon, 2005) and Canada (Sewell, 1973).

\section{Heterodera filipjevi (the rye cyst nematode)}

Heterodera filipjevi has been reported in eastern and northern Europe, the former USSR (Balakhnina, 1989), in Turkey where it is the most dominant and widespread species of CCN (Rumpenhorst et al., 1996), the Mediterranean region, in Central and West Asia and North America (Smiley et al., 2017). In a very recent survey were conducted in Azerbaijan and Kazakhstan, $H$. filipjevi was found to be the dominant species in both countries (Dababat et al., 2019c, 2020). Heterodera filipjevi is probably the major destructive nematode in wheat and barley growing areas, particularly in semiarid areas where nematode damage increases under drought stress conditions (Rivoal \& Cook, 1993; Nicol, 2002).

\section{Root-lesion nematodes (RLN)}

RLNs are ranked next to the CCNs in terms of its economic significance on wheat production systems (Castillo \& Vovlas, 2007). Currently, eight species of the RLN (P. brachyurus, $P$. coffeae, $P$. crenatus, $P$. neglectus, $P$. penetrans, $P$. pseudopratensis, $P$. thornei, and $P$. zeae) are known to affect roots of cereals (Rivoal \& Cook, 1993; Nicol et al., 2004) including wheat. Pratylenchus thornei, $P$. neglectus, $P$. penetrans, and $P$. crenatus are spreading widely and often co-exist in a single farm (Nicol et al., 2003; Smiley \& Nicol, 2009). The spread of RLN species depends mainly on the presence of a suitable host plant that supports the reproduction and conducive environmental factors primarily temperature (Castillo \& Vovlas, 2007). RLN species have been detected in $90 \%$ of dryland wheat-growing areas of the Pacific Northwest of the USA (Oregon, Washington, and Idaho), with a higher prevalence of $P$. neglectus and $P$. thornei (Smiley et al., 2004). Pratylenchus thornei is found to be a major nematode species in wheat production areas of the subtropical northern region of eastern Australia (Thompson et al., 2016). Pratylenchus thornei and $P$. neglectus are the most significant species of RLNs in damaging huge wheat-growing areas in the southern region of Australia (Vanstone et al., 2008). The occurrence of $P$. thornei and $P$. neglectus in diverse wheat-growing fields in Jordan has been documented (Al-Banna et al., 2015). Pratylenchus thornei, P. neglectus, and $P$. scribneri have also been characterized from wheat producing provinces of Isparta in Turkey (Sogut \& Devran, 2011; Imren et al., 2020). Pratylenchus neglectus, $P$. thornei, $P$. pseudopratensis and $P$. penetrans have been recorded in wheat-growing fields of Iran (Ghaderi et al., 2010) where $P$. thornei and $P$. neglectus were found prevalent (Pourjam et al., 1999). In Morocco, RLN were found to be the most economically important group of PPN in diverse wheatgrowing fields followed by the $H$. avenae group (Mokrini et al., 2017). The occurrence of $P$. penetrans, $P$. thornei, $P$. pinguicaudatus and $P$. pseudocoffeae, across different wheat-growing fields of Morocco has been reported 
(Mokrini et al., 2016). Sikora (1988) characterized both $P$. neglectus and $P$. penetrans along with $P$. thornei on barley and wheat-growing areas in Northern Africa and all these as well as P. zeae in Western Asia. Pratylenchus crenatus Loof, 1960, $P$. fallax Seinhorst, $P$. neglectus Rensch, 1924, P. penetrans Cobb and $P$. thornei (Sher \& Allen, 1953) were recorded in the east and southeast Anatolia (Yüksel, 1974). Pratylenchus thornei was documented in the Aegean and Thrace regions (Misirlioglu \& Pehlivan, 2007). In wheat, $P$. thornei is the most studied and reported species (Nicol et al., 2000). It was found in Algeria, Australia, Canada, India, Israel, Italy, Mexico, Morocco, Pakistan, Syria, Turkey, and former Yugoslavia (Nicol et al., 2004).

\section{Economic Importance of the Major Wheat Nematodes}

Globally, PPNs are among the most encountered soil-borne biotic agents that attack wheat and cause significant yield loss of up to $\$ 157$ billion per year (Bird \& Kaloshian, 2003; Abad et al., 2008). Wheat yield losses caused by PPN were assessed at $11 \%$ annually in South Africa (Keetch, 1989). Among the PPNs, the CCNs and the RLNs are the most extensively studied genera and have been detected and recorded from many countries (Cook \& Noel, 2002; Subbotin et al., 2010a; Dababat et al., 2015; Dababat \& Fourie, 2018) affecting wheat production, the supply chain and the global food security.

\section{Cereal cyst nematodes (CCNs)}

CCNs are responsible for significant losses in cereal which have been documented and reported (Rivoal \& Cook, 1993; Subbotin et al., 2010b; Imren et al., 2016, 2017; Mokrini et al., 2017; Fard et al., 2018) and most recently were intensively reviewed by Dababat and Fourie (2018). CCNs cause substantial economic losses especially in temperate and semi-arid regions of the world where the prevalent cropping system is monoculture (Rivoal \& Cook, 1993). Among the CCNs, $H$. avenae is the most damaging on wheat production. This biotrophic phytopathogen parasitizes wheat and other cereals. Wheat yield losses caused by $H$. avenae are less than $10 \%$ under the climatic conditions of northern Europe, but the damage can be significantly higher and exceed $50 \%$ in hotter and drier climates (Imren \& Elekcioğlu, 2014).

Economic losses due to Heterodera spp. on wheat have been documented across diverse regions of the world. The yield loss due to $H$. avenae has been reported $50 \%$ in wheat in Australia (Meagher, 1972), 40-92\% in Saudi Arabia (Ibrahim et al. 1999), 40-50\% in India (Mathur et al., 1980), and $40-50 \%$ in China (Peng et al., 2007), 26-96\% in Tunisia (Namouchi-Kachouri et al., 2007), 50\% in Israel (Mor et al., 1992) and $15-20 \%$ in Pakistan (Maqbool, 1988). Yield losses of $50 \%$ in wheat were recorded due to $H$. avenae and $H$. filipjevi in Norway (Holgado et al., 2004). Hassan et al. (2010) investigated the effect of $H$. avenae on both plant and nematode parameters such as plant growth, yield, and nematode multiplication in both durum and bread wheat cultivars under natural field conditions in Syria. Their finding indicated a $57 \%$ and $50 \%$ reduction of grain yields and $50 \%$ and $45 \%$ in straw yields in durum and bread wheat, respectively. In $\mathrm{H}$. avenae heavily infested irrigated fields of the USA $50 \%$ yield reduction of wheat has been reported (Smiley et al., 1994). Heterodera avenae caused significant yield loss in different wheat cultivars, varying from 4 to $26 \%$ in Adana Province of Turkey (İmren \& Elekcioğlu, 2014). A yield loss study was conducted in Rajasthan by Handa and Yadav (1991) was estimated up to $35 \%$ in wheat field.

Heterodera latipons is known to cause much lower damage when compared with $H$. avenae (Mor et al., 2008). However, the loss was found to be greatest in severe drought conditions and where the cropping system is monoculture (Philis, 1988, 1997). Durum wheat grain and straw losses due to $\mathrm{H}$. latipons is higher in semi-arid regions of Syria (Scholz, 2001). Heterodera latipons was found significantly reducing the yield of winter wheat by $55 \%$, spike height up to $36 \%$, shoot dry weight by $48 \%$, plant height up to $32 \%$ and root dry weight by $70 \%$ in Iran (Hajihasani et al., 2010a). This species was also found decreasing barley yield by $50 \%$ in Cyprus (Philis, 1988).

Yield losses in wheat due to $H$. filipjevi were reported in the range of $10-40 \%$ in China (Peng et al., 2007) and $40-92 \%$ in Saudi Arabia (Ibrahim et al., 1999). Smiley et al. (2005) reported $H$. filipjevi causing a 35\% yield loss in spring wheat in Oregon, USA. Recently Fard et al. (2018) estimated yield losses in wheat yield ranging between $20 \%$ and $25 \%$ in Iran by $H$. filipjevi. Wheat grain yield loss caused by $H$. filipjevi occurred even at lowest initial population density $(P i)$ and stretched to $48 \%$ yield loss with a Pi of 20 (eggs $+\mathrm{J} 2$ ) per gram of soil in Iran (Hajihasani et al., 2010b). A study was led to assess the effect of $H$. filipjevi on selected wheat cultivars in the field in Turkey, and the results showed that there was a significant grain yield reduction (42\%) in the studied wheat cultivars (Nicol et al., 2006). Similarly, a study to evaluate the impact of $H$. avenae on six spring wheat cultivars under naturally infested fields in Turkey showed that there was a significant yield reduction (25.7\%) (İmren \& Elekcioğlu, 2014). Sahin et al. (2008) reported that $H$. filipjevi was found infesting wheat fields in Haymana, Turkey where nematode population densities have reached (115 eggs and J2) per g soil. This may prove that $H$. filipjevi has great potential to cause damage and significant yield losses in wheat cultivation in Turkey and, this species caused yield loss in cultivars Seri-82 and Silverstar averaging $8.5 \%$ and 40.5\% in two-year experiments (Imren et al., 2020), respectively. Fard et al. (2018) conducted field experiments to investigate the impact of $H$. filipjevi on three wheat cultivars and their results showed significant reductions in grain yield in the range of $19.5 \%$ and $27.8 \%$. A micro plot experiment was executed to explore the impacts of $H$. filipjevi on the wheat yield of 
the cultivar Sardari with different $P i$ values (Hajihassani et al., 2010). They reported that nematode density of 2.5 (eggs $+\mathrm{J} 2$ ) per gram of soil caused a yield reduction of $48 \%$. Similarly, the damage caused by $H$. filipjevi to different wheat, barley, and triticale cultivars indicated a significant reduction in grain yield by $52 \%(40 \%-73 \%)$ in field conditions in Iran (Ahmadi et al., 2013). Yield losses of $42-50 \%$ on winter wheat were recorded due to $H$. filipjevi under rainfed conditions in Turkey (Nicol et al., 2006). In Iran, the yield loss caused by $H$. filipjevi was studied on winter wheat in the monoculture cropping system and resulted in $48 \%$ loss with a Pi density of 20 (eggs $+J 2$ ) per gram of soil while the aerial shoot yield loss reported reaching 40\% (Hajihasani et al., 2010a).

$\mathrm{CCN}$ has decreased yields in individual research trials or fields by $20 \%$ in Pakistan, $50 \%$ in Australia, $50 \%$ in Turkey, and $90 \%$ in Saudi Arabia (Dababat et al., 2015). Field infestation by CCN has caused $30-100 \%$ yield losses of wheat in different growing conditions (Bonfil et al., 2004; Nicol et al., 2007b). However, reports of crop losses at the magnitudes mentioned above do not precisely portray the scale of yield losses at a regional or national level since the documentation was mainly based on research plots located in infested areas of fields (Amjad et al., 2009). Furthermore, some early reports attributed to yield reduction due to $H$. avenae are recently reclassified as $H$. australis, $H$. filipjevi, $H$. latipons, or $H$. sturhani. However, numerous reports of regional or national wheat yield losses due to CCNs (Amjad et al., 2009).

\section{Root-lesion nematodes (RLN)}

Beside the CCNs, wheat is severely infected by several RLNs species of which $P$. neglectus and $P$. thornei are the destructive ones (Yu et al., 2012; Dababat et al., 2016). Wheat crop loss caused by $P$. neglectus can be as high as $85 \%$ (Smiley, 2010). Pratylenchus neglectus is found in Europe, Australia, and North America, which has not been studied much; nevertheless, $16-23 \%$ yield losses have been recorded in southern Australia by this species (Taylor et al., 1999). Studies in Oregon showed spring wheat yield losses of $36 \%$ associated with $P$. neglectus populations (Smiley et al., 2005). A 38-85\% wheat yield losses due to $P$. thornei have been reported and documented in Australia, 50\% in Oregon state of the USA, $12-37 \%$ in Mexico, and $70 \%$ in Israel (Nicol et al., 2004) and 32\% in Turkey (Gozel \& Elekçioglu, 2001). In Australia, Pratylenchus thornei is the most prevalent species of RLNs in wheat-growing areas and estimated to cause a loss of $\$ 33$ million annually (Brennan et al., 1992). Several studies conducted on spring wheat reported yield losses of elsewhere in the world up to $32 \%$ by $P$. neglectus, and $69 \%$ caused by $P$. thornei (McDonald \& Nicol, 2005; Thompson et al., 2008). Similar yield loss figures from this species have been stated for spring wheat in Oregon state (Smiley et al., 2005). Winter wheat yields were found reduced by $32 \%$ due to $P$. thornei in Colorado (Armstrong et al., 1993). Yield losses caused by $P$. thornei are assessed at $20 \%$ on wheat fields in Turkey (Toktay, 2008). Pratylenchus penetrans affects wheat crops yield by $10-19 \%$ in Canada (Nicol \& Rivoal, 2008). Moreover, these two RLN species were always found to occur simultaneously (Dababat \& Fourie, 2018).

\section{Current Management Approaches}

The population of $\mathrm{CNs}$ should be below the threshold levels to maintain acceptable quantities of production and reduce $\mathrm{CNs}$ damage. Damages caused by CNs can be most effectively controlled by integrating multiple strategies (Smiley \& Nicol, 2009; Riley \& Qi, 2015; Dababat \& Fourie, 2018). Eradication of whole CNs from infested fields is impossible; however, the protection of non-infested fields is crucial. Once an infestation of a field has occurred, the goal of management is to scale back the density of pathogens below threshold levels that cause economic damage. CNs can be managed by integrated pest management, including field sanitation, providing adequate irrigation and fertilization, crop rotation, resistant cultivars, etc.

\section{Field sanitation}

Phytosanitary procedures are often useful at a limited level; however, the limitation of localities is extremely difficult or impractical. Managing the movement of soil from infested to non-infested areas is a key to reduce nematodes movement. Detecting of CNs in newly infested fields is very difficult and takes times until it is noticed. Cereal nematodes are distributed through various ways such as soil transported by tools, plant products, animals, water, and wind (Smiley et al., 1994; Dawabah \& Al-Hazmi, 2007).

\section{Crop rotation}

Crop rotation aims to maintain a balance between the nematode populations and the frequency of cultivation. This is vital to ensure that sufficient time occurs after the nematode population increases on a susceptible/preferable host. This is a fundamental method to keep the CNs below the economic threshold for the next susceptible host. To implement the most effective crop rotation; the identity of the nematodes and the diversity of their hosts, the population dynamics, the degree of susceptibility of different hosts, and the relationship between the density of the nematodes and the lack of yield (crop tolerance) must be determined (Smiley et al., 2008). Damage by CNs is most prominent when the non-resistant host plants are grown. Dual combinations of resistant cultivars and noncereals can efficiently control CCNs. The utilization of crop rotation, however, could be completely different for RLNs due to their polyphagous nature (Nicol \& Rivoal, 2008). Therefore, a thorough understanding of the effectiveness of rotation is required for the successful implementation of crop rotation. Crop rotation, which includes broadleaf crops, corn, resistant wheat or barley or oat varieties, can significantly reduce 
the density of cyst nematodes (Rivoal \& Sarr, 1987; Fisher \& Hancock, 1991; Smiley et al., 1994).

\section{Host-Plant Resistance and Tolerance for Management of Cereal Nematodes}

The cultivation of host plants having tolerance or resistance is an efficient approach to control CNs (Thompson et al., 2008; Vanstone et al., 2008; Dababat et al., 2015). Both resistance and tolerance of a host are genetically independent characteristics. Varieties that are tolerant or resistant to one nematode species may not necessarily offer resistance or tolerance to another nematode species (Rivoal et al., 2001; McDonald \& Nicol, 2005; Smiley \& Nicol, 2009; Dababat et al., 2019a, b). Resistance to nematode is considered as the capacity of host plants to inhibit the reproduction rate of nematode (Cook \& Evans, 1987) (Table 1). Therefore, nematodes do not multiply, produce empty cysts, or reproduce poorly in resistant plants. Susceptibility is often genetically different from tolerance, where the later indicates the host's ability to resist a nematode attack i.e., the ability of the host to keep the potential of economic yield despite of the presence of nematodes (Stanton \& Stirling, 1997; Smiley et al., 2008, 2017).

Table 1. Definition of tolerance and resistance to nematode infection (Dababat, 2019)

\begin{tabular}{cccc}
\hline & & \multicolumn{2}{c}{ Nematode reproduction } \\
\cline { 3 - 4 } & & Low & High \\
\hline Plant & High & resistant/tolerant & susceptible/tolerant \\
Yield & Low & resistant/intolerant & susceptible/intolerant \\
\hline
\end{tabular}

Plants are considered resistant to nematodes when the expression levels of host genes associated with pathogenicity provide inhibition or reduction of the reproduction rate (Stanton \& Stirling, 1997). Resistance is a conclusion of a change in the equilibrium of the nematode-host reaction and complex processes in the host-parasite interactions (Stanton \& Stirling, 1997). The hypersensitive reaction to the nematode is the most common phenomenon of resistance, especially to sedentary endoparasites, and results in incompatible responses, which don't allow the nematode to feed. Less common mechanisms involved in resistance are plants not being able to attract nematodes, preventing eggs from hatching, the formation of toxins by plants, and resistance to penetration of nematodes (Smiley et al., 2008). Broader sustainability, however, may help solve problems with resistant varieties. Additionally, plant resistance is not present in many important varieties, and their effectiveness is generally limited to a few species/pathotypes of nematodes. This may result in varieties that tend to select virulent nematodes or related biotypes found in field populations (Whitehead 1998; Gheysen et al., 1996). The use of resistant varieties reduces the risk intensity for the next successive wheat, barley, or oats. Even if reproduction is restrained, infective juveniles often penetrate and damage the roots of resistant hosts, resulting in reducing the yield. Ideally, tolerance should be combined with resistance which is the best control option (Smiley et al., 2017). One of the advantages of using a tolerant host as a control strategy is that it does not exert selective pressure on the nematode as resistance. However, if the host is also susceptible, the nematode population can multiply, ultimately exceeding limits and causing yield loss (Rivoal et al., 2003; Smiley \& Nicol, 2009; Dababat \& Fourie, 2018). So far, mechanisms involved in the tolerance of nematodes and other plant parasites are not well understood. Several proposed mechanisms, including, for example, plant growth that goes beyond what is necessary to obtain economic benefits, growth compensating for damage caused by nematodes and growth due to lack of response to the presence of nematodes. Tolerant plants can produce a lower number of galled tissues than intolerant plants, which allows them to maintain photosynthesis for normal growth.

Marker-assisted selection (MAS) for $\mathrm{CN}$ resistance in wheat is commonly used to describe stable germplasm in selection programs around the world. The combination of greenhouse testing and marker-based reproduction has been used worldwide in studies aimed at reducing invasion and loss due to disease (Ogbonnaya et al., 2009). The marker-based selection strategy consists of two steps: pre-propagation for characterization of resistance sources and development of linked markers, followed by different sources (e.g. Cre3 on chromosome $2 \mathrm{BL}, \mathrm{Cre} 3$ on chromosome $2 \mathrm{DL}$ and $\mathrm{Cre} 8$ on chromosome 6B), specific PCR for tracking each gene using markers (Ogbonnaya et al., 2009).

Resistance to RLN is a quantitative trait, whereas resistance to $\mathrm{CCN}$ is genetically controlled by one gene (Mokrini et al., 2018). In the case of MAS, molecular markers have been developed to identify genes and quantitative indications of resistance in seedlings. Molecular markers have been successfully applied to identify resistance genes against $\mathrm{CN}$ in barley and wheat (Barr et al., 1998; Eagles et al., 2001; Ogbonnaya et al., 2001a, b; Barloy et al., 2007). Marker-based selection is used to improve genetic resistance, but effective resistance genes are not yet available in all cultures nor effective for all pathotypes. An extensive set of experiments using a tube, pot, or trial run screening determines whether the wheat, barley, oat, and triticale lines demonstrate resistance to a $\mathrm{CN}$ population. However, pathogenic phenotyping is tedious, timeconsuming and takes mostly a full season to complete. By developing dominant or co-dominant molecular markers and testing to determine resistance to the $\mathrm{CN}$ populations, leaf samples from small seedlings can be taken to determine the presence of resistance genes in 1-2 days, saving time and money. Therefore, selection based on the $\mathrm{CN}$ resistance markers in wheat is often used to describe resistance germplasm in breeding programs around the world. The combination of phenotyping and genotyping is used worldwide in 
Table 2. Principal sources of genes used to breed wheat for resistance to the cereal cyst nematode Heterodera species, unless stated otherwise

\begin{tabular}{|c|c|c|c|c|c|}
\hline Cereal Species & Cultivar or Line & Origin & Resistance Gene(s) ${ }^{\mathrm{a}, \mathrm{b}}$ & Response to Pathotypes ${ }^{b, c}$ & Use in Cultivars \\
\hline \multicolumn{6}{|l|}{ Wheat } \\
\hline \multirow[t]{6}{*}{ Triticum aestivum } & Loros, AUS10894 & $?^{d}$ & $\begin{array}{l}\text { Cre } 1^{\mathrm{e}} \text { (formerly } \mathrm{Ccn} 1 \text { ), } \\
\text { on chromosome } 2 \mathrm{BL}\end{array}$ & pR to several pathotypes & $\begin{array}{l}\text { NW Europe, Australia; } \\
\text { NW USA - under } \\
\text { evaluation }\end{array}$ \\
\hline & Katyil & Australia & Con1 & S, India & Australia \\
\hline & Festiguay & Australia & $\begin{array}{l}\text { Cre8 (formerly CreF) on } \\
\text { chromosome } 7 \mathrm{~L} \text { ? } \\
\text { Recent analysis suggests } \\
6 \mathrm{~B}\end{array}$ & pR to $\mathrm{Ha13}$ & Australia \\
\hline & AUS4930 = Iraq 48 & Iraq & $\begin{array}{l}\text { possibly identical genetic } \\
\text { location as } \\
\text { Cre1; also resistance to } \\
\mathrm{Pt}\end{array}$ & $\begin{array}{l}\mathrm{R} \text { to several pathotypes } \\
\text { and } \\
\text { Heterodera species and } \mathrm{Pt}\end{array}$ & $\begin{array}{l}\text { Australia, France, } \\
\text { CIMMYT- under } \\
\text { evaluation }\end{array}$ \\
\hline & Molineux & Australia & $\begin{array}{l}\text { chromosome } 1 \mathrm{~B} \\
\text { (14\% resistance) }\end{array}$ & $\mathrm{R}$ to $\mathrm{Ha} 13$ & Australia \\
\hline & $\begin{array}{l}\text { Raj MR1 (Raj Molya } \\
\text { Rodhak1) }\end{array}$ & $\begin{array}{l}\text { landrace from } \\
\text { Nigde, Turkey } \\
\text { AUS } 15854 \text { x J-24 }\end{array}$ & one dominant gene & $\begin{array}{l}\text { R only to some } \\
\text { populations of } H \text {. } \\
\text { avenae, appears } S \text { to } \\
\text { Indian } H \text {. filipjevi }\end{array}$ & $\begin{array}{l}\text { Released cultivar in } \\
\text { northern } \\
\text { India in } 2002\end{array}$ \\
\hline Triticum durum & $\begin{array}{l}\text { Psathias 7654, 7655, } \\
\text { Sansome, Khapli }\end{array}$ & $?$ & $?$ & $\begin{array}{l}\text { S to some pathotypes, } \\
\text { pR to others }\end{array}$ & \\
\hline \multicolumn{6}{|l|}{ Triticale and rye } \\
\hline \multirow[t]{4}{*}{ Triticosecale } & T701-4-6 & Australia & $\begin{array}{l}\text { CreR on chromosome } \\
6 \mathrm{RL}\end{array}$ & R to $\mathrm{Ha} 13$ & Australia \\
\hline & Drira (=Ningadhu) & Australia & $?$ & R to $\mathrm{Ha} 13$ & Australia \\
\hline & Tahara & Australia & $?$ & $\mathrm{R}$ to $\mathrm{Ha} 13$ & \\
\hline & Salvo & Poland & $?$ & & UK \\
\hline Secale cereale & R173 Family & & $\begin{array}{l}\text { CreR on chromosome } \\
6 \mathrm{RL}\end{array}$ & R to $\mathrm{Ha} 13$ & Australia \\
\hline \multicolumn{6}{|c|}{ Wild grass relatives of wheat } \\
\hline Aegilops tauschii & CPI 110813 & Central Asia & $\begin{array}{l}\text { Cre4 on chromosome } \\
2 \mathrm{DL}\end{array}$ & R to $\mathrm{Ha} 13$ & $\begin{array}{l}\text { Australian synthetic } \\
\text { hexaploid lines }\end{array}$ \\
\hline Aegilops tauschii & AUS18913 & $?$ & $\begin{array}{l}\text { Cre3 on chromosome } \\
2 \mathrm{DL}\end{array}$ & $\mathrm{R}$ to $\mathrm{Ha} 13$ & $\begin{array}{l}\text { Australian advanced } \\
\text { breeding lines }\end{array}$ \\
\hline $\begin{array}{l}\text { Aegilops peregrina (= } \\
\text { Ae. variabilis) }\end{array}$ & 1 & & $\begin{array}{l}\text { Cre(3S) with Rkn2 on } \\
\text { chromosome } 3 S \text {; CreX, } \\
\text { not yet located }\end{array}$ & & \\
\hline Aegilops longissima & 18 & $?$ & $?$ & $\begin{array}{l}\mathrm{R} \text { to four French } \\
\text { pathotypes and } \\
\text { Meloidogyne naasi }\end{array}$ & France \\
\hline Aegilops geniculata & $\begin{array}{l}\text { 79; MZ1, MZ61, MZ77, } \\
\text { MZ124 }\end{array}$ & $?$ & & $\begin{array}{l}R \text { and } p R \text { to several } \\
\text { pathotypes }\end{array}$ & $\begin{array}{l}\text { France - under } \\
\text { evaluation }\end{array}$ \\
\hline Aegilops triuncialis & TR-353 & $?$ & Cre7 (formerly CreAet) & $\begin{array}{l}R \text { and } p R \text { to several } \\
\text { pathotypes }\end{array}$ & $\begin{array}{l}\text { France - under } \\
\text { evaluation }\end{array}$ \\
\hline \multirow[t]{4}{*}{ Aegilops ventricosa } & VPM 1 & & $\begin{array}{l}\text { Cre5 (formerly } \mathrm{CreX} \text { ), on } \\
\text { chromosome } 2 \mathrm{AS}\end{array}$ & $\mathrm{R}$ to several pathotypes & $\begin{array}{l}\text { Spain - under } \\
\text { evaluation }\end{array}$ \\
\hline & $11 ; \mathrm{AP}-1, \mathrm{H}-93-8$ & & $\begin{array}{l}\text { Cre2 (formerly CreX) on } \\
\text { genome } \mathrm{N}^{v}\end{array}$ & & \\
\hline & 11; AP-1, H-93-8, H- & & Cre6, on chromosome & & \\
\hline & $93-35$ & & $5 N$ & & \\
\hline Madison & & & Cre9 & $\begin{array}{l}\text { https://pubmed.ncbi.nlm. } \\
\text { nih.gov/31433275/ }\end{array}$ & \\
\hline
\end{tabular}

a Sources: Reviews and references in Rivoal and Cook (1993), Cook and Rivoal (1998), McDonald and Nicol (2005), and Nicol and Rivoal (2007).

b Characterized single-gene resistance to cereal cyst nematode. ${ }^{C} \mathrm{R}=$ resistant, $\mathrm{pR}=$ partially resistant, $\mathrm{S}=$ susceptible. ${ }^{\mathrm{d}}$ ? $=$ no published scientific studies conducted. ${ }^{\mathrm{C}}$ Marker implemented in commercial breeding program - refer to Ogbonnaya et al. (2001b).

studies aimed at reducing invasion and disease loss (Ogbonnaya et al., 2009).

\section{Cereal cyst nematodes (CCN)}

Host resistance remains the most profitable and easiest to apply management process. However, it can only be used by farmers if the varieties have a tolerance (yield performance) that is comparable to other prevalently grown wheat varieties. The reasons for resistance in $\mathrm{CCN}$ populations around the world were compared, analysed, and gene localization and mapping were performed where possible (Table 2) (Rivoal et al., 2001; Dababat \& Fourie, 2018). More details about this section are under in the subtitle "Source of Resistance".

\section{Root-lesion nematodes (RLN)}

The use of resistant varieties is the most promising and economical tool to lower radically the RLN populations. More details about this part are under in subtitle sources of resistance for RLN. 


\section{Chemical control}

Repeated use of chemical nematicides has been shown to control CCNs in wheat (Smiley et al., 1994; Dababat et al., 2014; Fard et al., 2015; Riley \& Qi, 2015). The chemicals used to control nematodes can be divided into two main groups as contact or systemic nematicides and fumigants. Their costs usually limit the use of nematicides in intensive agriculture in which highquality plants are produced instead of the crops that need a larger area for cultivation such as grains (Smiley et al., 2017). Before 1980, several fumigants such as methyl bromide, dichloropropene, chloropicrin, dibromochloropropane (DBCP), ethylene dibromide (EDB), metham-sodium, and dazomet were frequently used against nematodes worldwide. These chemicals are not selective and affect all soil organisms including weeds, bacteria, fungi, and other invertebrates as well as nematodes (Dababat \& Fourie, 2018). Fumigants for nematode control show their effect by diffusion from the pore space of the gas phase and the water film that surrounds the soil particles. The movement and effectiveness of the fumigants are affected by the amount of organic matter that is not degraded in the soil, temperature, and texture of the soil. Substances with such fumigating properties quickly kill nematodes and then dissolve in the soil. All fumigants are generally phytotoxic and should be used as a pre-sowing treatment as excellent nematicides, which offer a high level of nematode control (Smiley \& Nicol, 2009; Smiley et al., 2008). There are two types of non-volatile nematicides, carbamates and organophosphates. Carbamates that are highly toxic to birds, mammals, fish, and humans include aldicarb, carbofuran, and oxamyl as most commonly used chemicals to control nematodes. Organophosphate and carbamate nematicides are usually applied to the upper few centimetres of the soil using planting equipment and are distributed downward with the movement of water. All non-volatile nematicides are highly toxic to mammals but are rarely phytotoxic at the concentrations used for field control (Smiley et al., 2017). Aldicarb is a pre-plant nematicide, very effective, and the most widely used nematicide. However, due to the increased level of microbial inactivation, aldicarb became ineffective after repeated use to control CCN in irrigated wheat areas in Saudi Arabia (Dawabah et al., 2015). In areas affected by aldicarb, repeated application of oxamyl to leaves causes a decrease in the density of $H$. avenae and an increase in the wheat yield. However, after two alfalfa products, the yield of wheat was not affected positively by oxamyl (Dawabah et al., 2015). Thus, oxamyl was proposed for regular use as part of a well-defined integrated CCN management system, which includes crop rotation, soil fertility, and sanitation management in the field, and rotating of the chemical composition of nematicides. The most common organophosphates are cadusaphos, terbufos, ethoprophos, and fenamiphos. Carbamates and organophosphates tend to have a hemostatic effect due to the action of nemastatic in action rather than nematoxic, which causes nematodes to become incapacitated, preventing egg hatching, reducing mobility, inhibiting feeding, and retarding development (Stirling et al., 1992). Nematodes are effective in the soil for a limited period (usually 2-6 weeks) and therefore tend to resume normal activity if chemicals are lost. Since nematodes need to be identified in a relatively short time frame, non-volatile nematicides are well suited for use in annual crops. However, to control nematodes in perennial plants, it is necessary to apply them more than one time in a year. The development of strategies for using these materials in drip irrigation systems expands their use in such situations (Stirling et al., 1992).

\section{Biological control}

Various bacteria, fungi, and invertebrates are known to prey or parasitize, and soils that suppress nematodes biologically have been identified (Davies et al., 1991). Economic constraints and environmental and safety concerns associated with early generation nematicides, however, have eliminated them on behalf of most farmers (Starr et al., 2007). Also, economical and effective biological nematicides for the treatment of CNs are currently not available in rain-fed farming systems. Efforts are underway to develop effective control of nematicides. Abamectin (a mixture of $\mathrm{B} 1 \mathrm{a}$ and $\mathrm{B} 1 \mathrm{~b}$ of avermectin) has been rated as a seed treatment for $\mathrm{CNs}$ treatment, but its advantages were not important to marginal wheat fields infected with cyst nematode $(H$. avenae) in Israel (Oka et al., 2009) and the United States (Smiley et al., 2012). However, when higher abamectin levels are used in seed furrows in China, grain yield has increased significantly (Zhang et al., 2017).

Bacillus firmus spores used in biological seed treatment in the United States also had little effect on grain yield and density after harvesting the cyst nematode ( $H$. avenae) (Smiley et al., 2012). The leaf application of a broad-spectrum insecticide/nematicide, spirometramat, which has mobility in both xylem and phloem (Safferling, 2008), reduced the density up to $78 \%$ after harvesting the cyst nematode $(H$. avenae), but did not improve the yield of summer wheat or influence the number of root galls on roots (Smiley et al., 2011). Cui et al. (2017) noted that treating winter wheat seeds with a mixture of fipronil plus chlorpyrifos, or either methylene (bis)thiocyanate plus thiamethoxam increases wheat yield and reduces the number of cysts in soils infected with the Chinese cyst nematodes populations ( $H$. filipjevi and $H$. avenae). More research is still needed to investigate the various combinations of these nematicides and other modern nematicides. Dababat et al. (2014) and Tian et al. (2007) examined reports that cyst nematode populations were reduced to densities not economically important by bacterial and fungal parasites of $\mathrm{J} 2 \mathrm{~s}$ and eggs. These organisms reduced the number of cysts formed, the ability to shed eggs, and the viability of J2s. However, there is currently no evidence that this phenomenon can be effectively 
manipulated as a practical management strategy in most parts of the world. It seems that there is no successful commercial practice for $\mathrm{CN}$ biological suppression.

\section{Other management strategies}

As a rule, it is not possible to set the time for growing plants. Hence, one of the most effective control options in cool and temperate regions where nematodes hatch in the spring is to plant winter crops in the fall and deepen in the roots to maximize hatching speed. Although this strategy is not as effective as rotation or genetic resistance, it can be a useful part of an integrated $\mathrm{CCN}$ pest management approach. The maximum yield loss from $\mathrm{CN}$ is seen when water or nutrients are limited by the maximum potential for plant growth at any time during the growing season. Thus, crop damage is minimized by ensuring optimal plant nutrition and, if possible, supplemental water during intervals of drought (Fard et al., 2015; Singh et al., 2009). Also, the CCN population can be reduced by planting susceptible hosts as traps until the main hatching period, thereby facilitating plant root invasion, which then dies before newly developing white females can produce viable eggs (Stone, 1961).

\section{Source of Resistance}

\section{(CCN) \\ Source of Resistance to Cereal cyst nematodes \\ Utilization of resistant and tolerant wheat} germplasm to combat CCNs is an eco-friendly and costeffective strategy (Trudgill, 1991). However, such resistant cultivars should be continuously grown on a particular area which leads to lower negligible population densities (Ali et al., 2019). Sowing of these resistant varieties primarily results in lower reproduction rates in the invading nematode species (Cui et al., 2016). This is a well-known fact that almost all of the reported resistances in commercial cultivars against $\mathrm{CCN}$ are introgressions of a single dominant gene (Rivoal et al., 2001; Nicol, 2002; Nicol et al., 2003; McDonald \& Nicol, 2005; Nicol \& Rivoal, 2008; Smiley \& Nicol, 2009).

The very early discovery of gene harbouring resistance to $H$. avenae was carried out from barley from Sweden in 1920, nevertheless, this gene was completely characterized in 1961 (Andersen, 1961). This was followed by a huge amount of work aimed at the development of CCN resistant cultivars by several scientists in the coming decades (Smiley et al., 2017). Later, a $H$. avenae resistance locus was reported in barley on chromosome $2 \mathrm{H}$ (Ha2 locus) and confirmed by using RFLP markers (Kretschmer et al., 1997). The same molecular technique was used by Barr et al. (1998) which led to the mapping of $\mathrm{Ha} 4$ locus on chromosome $5 \mathrm{H}$ in barley.

Many sources of resistance to different diseases in bread wheat are derived from wild relatives of wheat via conventional breeding programmes (Ogbonnaya et al., 2001a). Overall the resistance sources to $H$. avenae comprise 9 resistance loci/genes (formerly called: Cereal root eelworm: Cre) which were introgressed into bread wheat from other Triticum spp. and Aegilops (Barloy et al., 2007). These loci range from $\mathrm{Cre} 1$ to $\mathrm{Cre} 9$ in addition to $\mathrm{CreR}$ and $\mathrm{CreV}$. Cre1, Cres and Cre9 originate from $T$. aestivum itself, Cre2, Cre5 and Cre6 from Aegilops ventricosa, Cre3 and Cre4 from Aegilops tauschii; Cre7 from Aegilops triuncialis L. However, Dasypium villosum L. is the source for $\mathrm{CreV}$ while CreR was reported from rye (Barloy et al., 2007). All these loci are well documented and mapped on the wheat chromosomes; however, CreX and $\mathrm{CreY}$ are sourced from Ae. variabilis are not well characterized for their inheritance mode and their locations are still unknown on the wheat chromosomes (Barloy et al., 2007).

Different studies showed that the Cre1 locus is relatively more responsive to $H$. avenae population from Europe, North America and North Africa (Table 2) whereas this locus is less responsive to Australian and Asian populations of CCNs (Rivoal et al., 2001; Mokabli et al., 2002). In addition to different responsiveness of Cre loci in different countries and continents, the effectiveness of $\mathrm{Cre}$ genes varies in response to different species of CCNs (Ali et al., 2019). For instance, Cre1 gene was active in response to Turkish populations of $H$. filipjevi. While, Cre3 lost its effectiveness to Turkish populations of $H$. filipjevi (Smiley et al., 2017). However, the Cre3 gene was found to be active against the Australian populations of $H$. avenae (Vanstone et al., 2008), but this resistance was lost to $H$. avenae populations from Europe (de Majnik et al., 2003; Safari et al., 2005). On the other hand, Cre2 and Cre 4 loci originated from Aegilops spp. demonstrated expansive degree of resistance against numerous Heterodera spp. and their various pathotypes (Nicol et al., 2001). CIMMYT coordinates the work of the international root resistance nursery, which includes seven of the Cre genes to determine the value of these genes globally. Quantitative trait loci (QTLs) associated with CCN resistance were also linked to chromosomes $1 A, 1 D, 4 D$, 5A, 5B, 5D, 6A, 6B, 7A, and 7D (Mulki et al., 2013; Dababat et al., 2016). Eleven DArT markers have also been reported (Dababat et al., 2016). These areas of resistance could soon become molecular tools for wheat-growing programs.

Nonetheless, the resistance against CNs must be coupled with a tolerance response to achieve sustainable productivity in wheat (Brown, 1987). Tolerant cultivars have been demonstrated to show better grain yield with a considerable degree of nematode control (Smiley, 2009). As compared to resistance response, under field conditions, tolerance response is assessed by relating grain yield of nematicide treated control plot and a nematode infested untreated plot (Brown, 1987; Smiley \& Marshall, 2016). This displays real-time assessment of wheat cultivars against nematode infestations which are 
primarily based on grain yield and development of nematodes on the plant roots.

The tolerance trait is mainly a result of specific attributes of physiological response and root growth of the plants in response to nematode infestation (Stanton \& Fisher, 1988; Volkmar, 1990). During the establishment of syncytia, in case of cereal cyst nematodes, root growth and development is extremely restricted because of the abbreviation of root and sometimes proliferation in the form of adventitious roots, and root depth is largely decreased. This leads to unavailability of water and water-soluble nutrients that leads to a decrease in the overall productivity of the plants. Most of the time, the resistance response is negatively correlated with grain yield and during the absence of nematodes, susceptible cultivars tend to have a higher yield as compared to resistant wheat varieties (Wilson et al., 1983). This is why, the farmers sometimes do not prefer resistant varieties due to lower grain yields as compared to susceptible ones in noninfested soils (Rivoal \& Cook, 1993). Conversely, a coupling of tolerance and resistance responses in wheat cultivars may lead to enhanced per unit production and profitability (Smiley et al., 2017).

\section{(RLN)}

Sources of Resistance to Root-lesion nematodes

Deployment of host resistance is considered one of the most ideal and economical strategies to reduce the detrimental effects caused by the RLN populations (Castillo et al., 1998). In contrast to the inherited single gene for resistance to CCNs, resistance to RLNs is largely quantitative. This kind of horizontal resistance is good in a sense that there is always some degree of resistance available, however, on the other hand, due to additive effects from several genes; it is sometimes difficult to develop effective resistance. In addition to native species of wheat from middle East, wild relatives of wheat i.e., Aegilops species are important sources of resistance against $P$. thornei (Hollaway et al., 2000; Nombela \& Romero 1999; Nicol et al., 1999, 2001, 2003; Sheedy et al., 2008; Thompson \& Haak, 1997; Thompson et al., 1999; Tokay et al., 2006; Zwart et al., 2004, 2005). Several accessions showed a resistance to both $P$. thornei and P. neglectus (Dababat et al., 2016, 2019; Nicol et al., 2007a; Sheedy et al., 2007; Zwart et al., 2005). By using double-resistance sources in commercial varieties, farmers no longer need to identify Pratylenchus at the species level before deciding on a sustainable variety.

Numerous sources of resistance to RLN have been described in the wheat germplasm Table 3 (Taylor et al., 2000; Thompson \& Haak, 1997; Toktay et al., 2012). For instance, resistant resources to $P$. thornei in wheat (Thompson et al., 1999, 2009; Vanstone et al., 1998) and P. neglectus (Thompson et al., 1999) are already known. Bread wheat line "GS50a" was significantly reported to be the first source of resistance to $P$. thornei from Australia, which it was primarily selected from the cultivar "Ghatcher" (Thompson \& Clewett, 1986). Ten times lower RLN reproduction was found on GS50a in comparison with the local control (Thompson et al., 1999). A reasonable number (i.e., 274 accessions) of Iranian landraces of wheat were assessed for resistance to RLN and 25 of those accessions showed more resistance than that of GS50a line (Sheedy \& Thompson 2009). Similarly, Thompson et al. (2009) performed the screening experiment with wheat accessions from North Africa and West Asian regions and found some additional sources resistant to $P$. thornei.

Mapping of QTLs and phenotypic identification of resistance sources have been largely used to identify

Table 3. Principal sources of genes used to breed wheat for resistance to root-lesion nematodes Pratylenchus neglectus $(P n)$ and P. thornei (Pt)

\begin{tabular}{|c|c|c|c|c|c|}
\hline $\begin{array}{l}\text { Cereal } \\
\text { Species }\end{array}$ & Cultivar or Line & Origin & Resistance Gene(s) ${ }^{a, b}$ & $\begin{array}{l}\text { Response to } \\
\text { Pathotypes }{ }^{b, c}\end{array}$ & Use in Cultivars \\
\hline \multirow[t]{8}{*}{$\begin{array}{l}\text { Triticum } \\
\text { aestivum }\end{array}$} & GS50a & $\begin{array}{l}\text { Australia - reselection } \\
\text { from cv. Gatcher }\end{array}$ & Major QTL mapped to 6D & & Australia \\
\hline & AUS4930=Iraq 48 & Iraq & QTLs mapped to $1 B, 2 B$, and $6 \mathrm{D}$ & $\begin{array}{l}\mathrm{R} \text { to } \mathrm{Pt} \text { but also } \\
\text { portrays } \mathrm{R} \text { to } \mathrm{Ha}\end{array}$ & $\begin{array}{l}\text { Australia, CIMMYT - } \\
\text { under investigation }\end{array}$ \\
\hline & $\begin{array}{l}\text { Reselection of } \\
\text { Excalibur }\end{array}$ & $\begin{array}{l}\text { Australian cv. } \\
\text { Excalibur }\end{array}$ & QTL mapped to 7AL & $\mathrm{R}$ to $P n(R / n n 1)$ & Australia, CIMMYT \\
\hline & $\begin{array}{l}\text { Croc_1/Ae. } \\
\text { tausch. } \\
\text { (224)//Opata }\end{array}$ & Primary synthetic & QTLs mapped to $1 \mathrm{~B}$ and $3 \mathrm{~B}$ & $\mathrm{R}$ to $P t$ & CIMMYT \\
\hline & CPI133872 & Primary synthetic & QTLS mapped to 2B, 4D, 6A, and 6D & R to $P t$ and $P n$ & Australia \\
\hline & W-7984 x Opata 85 & & QTLs mapped to 2B and 6D & $\mathrm{R}$ to $P t$ & Australia \\
\hline & AUS4926 & $\begin{array}{l}\text { Middle eastern } \\
\text { landrace }\end{array}$ & QTLS mapped to 1B, 2B, 3B, and 6D & $\mathrm{R}$ to $P t$ & Australia \\
\hline & AUS13124 & $\begin{array}{l}\text { Middle eastern } \\
\text { landrace }\end{array}$ & QTLs mapped to $2 B, 3 B, 6 D$, and $7 \mathrm{~A}$ & $\mathrm{R}$ to $P t$ & Australia \\
\hline $\begin{array}{l}\text { Aegilops } \\
\text { tauschii }\end{array}$ & CPI 110872 & & & R to $P t$ and $P n$ & \\
\hline $\begin{array}{l}\text { Aegilops } \\
\text { geniculata }\end{array}$ & $\begin{array}{l}\text { MZ10, MZ61, } \\
\text { MZ96, MZ144 }\end{array}$ & $\begin{array}{l}\text { Middle East and } \\
\text { West Asia }\end{array}$ & & $\begin{array}{l}\text { pR to Pt., several also } \\
\text { portray R to } \mathrm{Ha}\end{array}$ & \\
\hline
\end{tabular}


resistance sources against RLNs. The QTLs linked to resistance against $P$. thornei resistance are mapped on different chromosomes of bread wheat i.e., 1B, 2B, 3B, 4D, 6D, and 7A (Schmidt et al., 2005; Toktay et al., 2006; Zwart et al., 2005). RInn1 locus which is located on the 7A chromosome offers substantial resistance to $P$. neglectus at the seedling stage (Williams et al., 2002). According to Williams et al. (2002), RInn1 originated from Australian variety 'Excalibur', has been identified and validated for its better degree of resistance against $P$. neglectus. Similarly, another locus conferring resistance to $P$. neglectus has been characterized and identified on the 4D chromosome (Zwart et al., 2005). The relationships between resistance reactions and markers were adequately constant to show Pratylenchus in wheat the possibility of using the marker selection to increase resistance. $R \operatorname{lnn} 1$ marker has been successfully used following this strategy and is actively implemented as part of international wheat breeding programs in CIMMYT at a global level and in Australia (Williams et al., 2002).

$P$. thornei is the most investigated species of RLN in the resistance studies because it is the most dominant RLN species around the globe. As compared to $P$. thornei, $P$. neglectus is less investigated for screening and resistance studies. However, combined resistance studies and development of resistance to both RLN species is desirable as these species are present in the same field with mixed populations (Thompson et al., 2010). Moreover, Smiley \& Nicol (2009) reported that resistance and tolerance response to $P$. thornei and $P$. neglectus is genetically independent because of the observation that wheat cultivars tolerant or resistant to one species did not show a similar response against the other species.

Multiplication rate of RLN is high on susceptible varieties of wheat that leads to a reduction in growth and grain yield; however, a resistant cultivar supports lower nematode reproduction leading to lower yield losses. By contrast, a cultivar with tolerance response is still able to yield better even when the population densities of RLN are higher in the field (Thompson et al., 1999). The early sources with superior tolerance response to $P$. thornei i.e., cultivars like Baxter, Pelsart and Sunvale (Brennan et al., 1994; Ellison et al., 1995; Thompson et al., 1999) were identified through targeted screening to curtail the damaging effects of RLN. Thompson et al. (1995) reported that the abovementioned tolerant lines led to a $30 \%$ yield enhancement over the commercial varieties of wheat being grown in the field at that particular time. This necessitates the development of cultivars in which the resistance response should be combined with tolerance to combat RLN. The most comprehensive investigation regarding the breeding of tolerant and resistant lines to Pratylenchus spp. is done by Australian scientists. This research demonstrated cultivation of a tolerant wheat cultivar after nematicide treatment and/or in the nematode-free fields is one of the better options for RLN management (Thompson et al., 2008).

Phenotypic identification of resistance was used in combination with molecular biology to investigate the genetic control and localization of resistance genes and to identify resistance markers. The locations of QTL associated with resistance to $P$. thornei have been identified on chromosomes 1B, 2B, 3B, 4D, 6D, and 7A (Schmidt et al., 2005; Zwart et al., 2005, 2006; Toktay et al., 2006; Dababat et al., 2016). A molecular marker may describe the presence of the RInn1 gene on the 7A chromosome, which offers resistance to $P$. neglectus in seedlings (Williams et al., 2002). Another resistance gene for $P$. neglectus was characterized on the 4D chromosome (Zwart et al., 2005). The relationships between resistance reactions and markers were adequately constant to show Pratylenchus in wheat the possibility of using the marker selection to increase resistance. This process is actively implemented as part of international wheat breeding programs in Australia and CIMMYT using the RInn1 marker (Williams et al., 2002).

\section{Transgenic resources}

Conventional breeding for enhancement of nematode resistance or tolerance often demands large scale screening of germplasm accessions to locate resistance loci and validation of these loci using appropriate molecular markers (Ali et al., 2019). However, the employment of transgenic strategies provides a potential alternative to conventional breeding programmes. The transgenic approach provides both heterologous and homologous transfer of validated natural as well as synthetic resistance genes. There are several transgenic strategies available for the developing transgenic wheat resistance to both $\mathrm{CCN}$ and RLN. We have recently provided a detailed review regarding different transgenic methods to develop nematode resistance in plants (Ali et al., 2017a).

This review indicates the use of host induced gene silencing approach to suppress effector genes which are vital for the establishment of nematodes on plant roots (Ali et al., 2017a, 2017b). Although this strategy is not employed for the development of nematode resistance against CCN and RLN, except a study where 4 genes involved different physiological process of $H$. avenae were silenced through in vitro silencing (Gantasala et al., 2015). The researchers reported $26 \%, 60 \%$ and $71 \%$, $26 \%$, and $60 \%$ decrease in the number of eggs and females because of silencing of genes encoding intron binding protein, epsin, and polyadenylate binding protein, respectively. Conversely, eggs and females were increased up to $25 \%$ due to the silencing of nuclear hormone receptor. Likewise, the $H$. avenae annexin like protein (Ha-annexin) was supposed to be active for the suppression of basal defence responses (Chen et al., 2015). HIGS of Ha-annexin led to lower nematode development of $H$. avenae in wheat. Most recently, genes coding for two $H$. avenae venom allergen-like 
effector proteins (HaVAP1 and HaVAP2) involved in the suppression of programmed cell death were silenced and characterized (Luo et al., 2018).

Transgenic expression of protease inhibitors (PIs) like cystatins, trypsin inhibitors and serine proteinase inhibitors are also good resources for the development of CCN and RLN resistance in wheat. PIN2, a serine proteinase inhibitor from potato was transformed into the durum wheat which enhanced $H$. avenae resistance in wheat (Vishnudasan et al., 2005). Other genetic sources include nematicidal proteins like Bt-toxins and lectins (Ali et al., 2017b). Similarly, use of anti-invading chemodisruptive peptides and a combination of proteinase inhibitors and chemodisruptive peptides could be a potential approach to increase resistance against CCN and RLN in wheat (Ali et al., 2017b, 2019).

\section{Conclusion and Future Remarks}

Global food security largely depends on sustainable wheat production to feed the everincreasing population. CCN and RLN are a serious threat to global wheat production and must be managed through appropriate combating strategies. The access to genomic resources like genome sequence and resequence information, and wheat worldwide germplasm collection centres including wild wheat germplasm collections may provide unique opportunities for wheat genetic improvement. Moreover, the presence of several genome-wide association studies and genome editing technologies could also help for further improvement to enhance CCNs and RLNs resistance in wheat. This article provides the latest information regarding the progress made in the identification and characterization of resistance genes from different sources and its utility against CCNs and RLNs, which will attract the attention of the scientific community and other relevant stakeholders.

This particularly emphasizes the enhancement of resistant wheat germplasm using both conventional as well as modern approaches. In addition to markerassisted selection (MAS) and common selection approaches, use of genotyping by sequencing (GBS) followed by genome-wide association studies (GWAS) could be used for the development of nematode resistance in wheat (Pariyar et al., 2016b). Likewise, assessment to complete genome sequences of different cereal nematodes could lead to identifying novel effector encoding genes for manipulation via hostinduced gene silencing (HIGS) approach (Consortium, 2012; Mayer et al., 2014). Moreover, the recently completed sequencing of the wheat genome has generated a huge opportunity that could be exploited to study and understand molecular wheat-nematode interactions leading to the development of nematode resistant wheat (Appels et al., 2018).

Moreover, transcriptome studies for both wheat and barley in response to CCN and RLN infection could provide information and could be manipulated through modification of gene expression in wheat roots aimed at the development of nematode resistance (Ali et al., 2019). Transgenic expression of rice cystatins proteinase inhibitor has recently been carried out in several crops i.e. banana, tomato, plantain, and potato (Ali et al., 2017a). Cystatins are readily digestible in the human digestive system and their use might have limited biosafety and environmental issues (Tripathi et al., 2015). These PIs could be potential candidates to be used for transgenic expression to incorporate $\mathrm{CCN}$ and RLN resistance in wheat. Combination of various techniques and resources like HIGS, use of proteinase inhibitors and root-specific expression of anti-invading nematode repellent peptides could amplify nematode resistance in wheat (Ali et al., 2017a). More recently, application of CRISPR/Cas9 system could be used for targeted genome editing for enhancement of CCN and RLN resistance in bread wheat (Kumar \& Jain, 2015).

\section{Conflict of Interest}

The authors declare that the research was conducted in the absence of any commercial or financial relationships that could be construed as a potential conflict of interest.

\section{Authors Contribution}

$A D$ and $S A$ conceived and designed the review. $A D$, $\mathrm{SA}, \mathrm{MAA}, \mathrm{FT}, \mathrm{TP}$, and $\mathrm{MI}$ wrote and edit the review. All authors contributed to the article and approved the submitted version.

\section{References}

Abad, P., Gouzy, J., Aury, J. M., Castagnone-Sereno, P., Danchin, E. G., Deleury, E., Perfus-Barbeoch, L., Anthouard, V., Artiguenave, F., Blok, V. C., Caillaud, M. C., Coutinho, P. M., Dasilva, C., De Luca, F., Deau, F., Esquibet, M., Flutre, T., Goldstone, J. V., Hamamouch, N. \& Wincker, P. (2008). Genome sequence of the metazoan plant parasitic nematode Meloidogyne incognita. Nature Biotechnology, 26, 909-915. https://doi.org/10.1038/nbt.1482

Ackerman, F., \& Stanton, E. A. (2008). Can climate change save lives? A comment on economy-wide estimates of the implications of climate change, Human Health and ecological economics, 66, 8-13.

https://doi.org/10.22004/ag.econ.37240

Ahmadi, A. R., Tanha Maafi, Z., \& Abeyat, T. (2013). Reaction of some wheat, barley and triticale cultivars to cereal cyst nematode, Heterodera filipjevi, under field conditions in Khuzestan province. Plant Protection Journal, 6, 123-132.

Al-Banna, L., Al Abded, A., Fattash, I., Khrfan, W., Lafi, H., Abu Shweimeh, T., Mazrawi, D., \& Abu Al Ragheb, I. (2015). Current status of cyst nematodes attacking cereals in Jordan. Proceedings of the Fifth International Cereal Nematode Initiative Workshop, Ankara, 12-15.

Ali, M. A., Azeem, F., Abbas, A., Joyia, F. A., Li, H., \& Dababat, A. A. (2017a). Transgenic strategies for enhancement of 
nematode resistance in plants. Frontiers in Plant Science, 8, 750. https://doi.org/10.3389/fpls.2017.00750

Ali, M. A., Azeem, F., Li, H., \& Bohlmann, H. (2017b). Smart parasitic nematodes use multifaceted strategies to parasitize plants. Frontiers in Plant Science, 8, 1699. https://doi.org/10.3389/fpls.2017.01699

Ali, M. A., Shahzadi, M., Zahoor, A., Dababat, A. A., Toktay, H., Bakhsh, A., Nawaz, M. A., \& Li, H. (2019). Resistance to cereal cyst nematodes in wheat and barley: an emphasis on classical and modern approaches. International Journal of Molecular Science. 20(2), 432. https://doi.org/10.3390/ijms20020432

Andersen, S. (1961). Resistens mod Havreal Heterodera avenae in: Meddelelse. Konelige. Veterinærog Landbrugets Plantekultur. Copenhagen, Denmark.

Andersson, S. (1974). Heterodera hordecalis n. sp. (Nematoda: Heteroderidae) a cyst nematode of cereals and grasses in southern Sweden. Nematologica, 20, 445-454. https://doi.org/10.1163/187529274X00078

Anon (2005). Heterodera latipons. Distribution Maps of Plant Disease. Wallingford: CAB Int.

Appels, R., Eversole, K., Feuillet, C., Keller, B., Rogers, J., Stein, N., Pozniak, C. J., Stein, N., Choulet, F., Distelfeld, A., Eversole, K., Poland, J., Rogers, J., Ronen, G., Sharpe, A. G., Barad, O., Baruch, K., Keeble-Gagnere, G., Mascher, M., ..., \& Wang, L. (2018). Shifting the limits in wheat research and breeding using a fully annotated reference genome. Science 361 .

https://doi:10.1126/science.aar7191

Armstrong, J. S., Peairs, F. B., Pilcher, S. D., \& Russell, C. C. (1993). The effect of planting time insecticides and liquid fertilizer on the Russian wheat aphid (Homoptera: Aphididae) and the lesion nematode (Pratylenchus thornei) on winter wheat. Journal of the Kansas Entomological Society, 69-74.

Baklawa, M., Niere, B., Heuer, H. \& Massoud, S. (2015). Characterisation of cereal cyst nematodes in Egypt based on morphometrics, RFLP and rDNA-ITS sequence analyses. Nematology, 17, 103-115. https://doi.org/10.1163/15685411-00002855

Balakhnina, V. P. (1989). Resistance of varieties of Triticum durum Desf. and Triticum aestivum $L$. to the oat cyst nematode. Gelmintologiya Segonya: Problemy Perspectivy. Tezisy Dokladov Nauchnoi Konferentsii, Moscow: USSR.4-6 April. 36-37.

Barloy, D., Lemoine, J., Abelard, P., Tanguy, A. M., Rivoal, R., \& Jahier, J. (2007). Marker-assisted pyramiding of two cereal cyst nematode resistance genes from Aegilops variabilis in wheat, Molecular Breeding. 20: 31-40. https://doi.org/10.1007/s11032-006-9070-x

Barr, A. R., Chalmers K. J., Karakousis, A., Kretschmer, J. M., Manning, S., Lance, R. C. M., Lewis, J., Jeffries, S. P. \& Langridge, P. (1998). RFLP mapping of a new cereal cyst nematode resistance locus in barley, Plant Breeding, 117, 185-187. https://doi.org/10.1111/j.14390523.1998.tb01477.x

Bird, D. M., \& Kaloshian, I. (2003). Are roots special? Nematodes have their say. Physiological and Molecular Plant Pathology, 62, 115-123. https://doi.org/10.1016/S0885-5765(03)00045-6

Bockus, W. W., Bowden, R. L., Hunger, R. M., Morrill, W. L., Murray, T. D., \& Smiley, R. W. (2010). Compendium of wheat diseases and pests. $3^{\text {rd }}$ edition. The American Phytopthological Society Press. St. Paul, Minnesota.
Bonfil, D. J., Dolgin, B., Mufradi, I., \& Asido, S. (2004). Bioassay to forecast cereal cyst nematode damage to wheat in fields. Precision Agriculture, 5, 329-344. https://doi.org/10.1023/b: prag.0000040804.97462.02

Brennan P. S., Martin D. J., \& Thompson J. P. (1994). Triticum aestivum ssp. vulgare (bread wheat) cv. Pelsart. Australian Journal of Experimental Agriculture, 34, 864865. https://doi.org/10.1071/ea9940873

Brennan, J. P., Murray, G. M., \& Ballantyne, B. (1992). Private and social costs of growing cultivars susceptible to diseases. Annual Conference of the Australian Agricultural Economics Society, Canberra, Australia.

Brown, R. (1987). Control strategies in low-value crops. In R. Brown \& B. Kerry (Eds), Principles and practice of nematode control in crops, (Sydney, Australia: Academic Press), 351-387.

Castillo, P., \& Vovlas, N. (2007). Pratylechus (Nematoda: Pratylechidae): Diagnosis, Biology, Pathogenicity and Management. Leiden, Boston. https://doi.org/10.1163/ej.9789004155640.i-523

Castillo, P., Vovlas, N., \& Jimenez-Diaz, R. M. (1998). Pathogenicity and histopathology of Pratylenchus thornei populations on selected chickpea genotypes, Plant Pathology, 47, 370-376.

https://doi.org/10.1046/j.1365-3059.1998.00240.x

Chen, C., Cui, L., \& Chen, Y. (2017). Transcriptional responses of wheat and the cereal cyst nematode Heterodera avenae during their early contact stage. Scientific Reports, 7, 14471. https://doi.org/10.1038/s41598-01714047-y

Chen, C., Liu, S., Liu, Q., Niu, J., Liu, P., \& Zhao, J. (2015). An annexin-like protein from the cereal cyst nematode Heterodera avenae suppresses plant defense, Plos One, 10. https://doi.org/10.1371/journal.pone.0122256

Consortium, I. B. G. S. (2012). A physical, genetic and functional sequence assembly of the barley genome. Nature, 491, 711-716. https://doi.org/10.1038/nature11543

Cook, R., \& Evans, K. (1987). Resistance and tolerance. In R. Brown \& B. Kerry (Eds), Principles and practice of nematode control in crops. Sydney, Australia: Academic Press. 179-231.

Cook, R., \& Noel, G.R. (2002). Cyst nematodes: Globodera and Heterodera species. In R. Cook, J. Bridge \& J. L. Star (Eds), Plant resistance to parasitic nematodes. $C A B$ International, Wallingford, 71-105.

Cui, J. K., Huang, W. K., Peng, H., Yan L.V., Kong, L. A., \& DeLiang, P. (2017). Efficacy evaluation of seed-coating compounds against cereal cyst nematodes and root lesion nematodes on wheat. Plant Disease, 101, 428433. https://doi.org/10.1094/PDIS-06-16-0862-RE

Cui, L., Sun, L., Gao, X., Song, W., Wang, X. M., \& Li, H. L., (2016). The impact of resistant and susceptible wheat cultivars on the multiplication of Heterodera filipjevi and H. avenae in parasite-infected soil. Plant Pathology, 65, 1192-1199. https://doi.org/10.1111/ppa.12495

Curtis, B. C. (2002). Wheat in the world. In B. C. Curtis, S. Rajaram \& H. Gomez Macpherson (Eds). Bread wheat improvement and production. F.A.O., Rome, 1-17.

Dababat, A. A., İmren, M., Pridannikov, M., Özer, G., Zhapayev, R., Mokrini, F., Otemissova, A., Yerimbetova, A., \& Morgounov, A. (2020). Plant-parasitic nematodes on cereals in northern Kazakhstan. Journal of Plant Diseases and Protection, 1-9. https://doi.org/10.1007/s41348020-00306-0 
Dababat, A. A., Yildiz, Ş., Ciftci, V., Duman, N., \& Imren, M. (2019a). Occurrence and seasonal variation of the root lesion nematode on cereals in Bolu, Turkey. Turkish Journal of Agriculture and Forestry, 43, 21-27. https://doi.org/10.3906/tar-1805-52

Dababat, A. A., \& Fourie, H. (2018). Nematode Parasites of Cereals. In R.A. Sikora, D. Coyne, J. Hallmann and P. Timper (Eds.). Plant parasitic nematodes in subtropical and tropical agriculture. Wallingford, UK, CAB Int., 163221.

Dababat, A. A., Erginbas-Orakci, G., Toumi, F., Braun, H. J., Morgounov, A. I., \& Sikora, R. A. (2018). IPM to control soil-borne pests on wheat and sustainable food production. Arab Journal of Plant Protection, 4, 37-44. https://doi. 10.22268/AJPP-036.1.037044

Dababat, A. A., Erginbas-Orakci, G., Toktay, H., Imren, M., Akin, B., Braun, H. J., \& Dreisigacker, S. (2014). Resistance of winter wheat to Heterodera filipjevi in Turkey. Turkish Journal of Agriculture and Forestry, 38, 180-186. https://doi.org/10.3906/tar-1305-47

Dababat, A. A., Ferney, G. B. H., Erginbas-Orakci, G., Dreisigacker, S., \& Imren, M. (2016). Association analysis of resistance to cereal cyst nematodes (Heterodera avenae) and root lesion nematodes (Pratylenchus neglectus and $P$. thornei) in CIMMYT advanced spring wheat lines for semi-arid conditions. Breeding Science, 15158. https://doi.org/10.1270/jsbbs.15158

Dababat, A. A., Imren, M., Erginbas-Orakci, G., Ashrafi, S., \& Yavuzaslanoglu, E. (2015). The importance and management strategies of cereal cyst nematodes, Heterodera spp., in Turkey. Euphytica, 202, 173-188. https://doi.org/10.1007/s10681-014-1269-z

Dababat, A. A., Mokrini, F., Laasli, S. E., Yildiz, Ş., ErginbasOrakci, G., \& Duman, N. (2019b). Host suitability of different wheat lines to Pratylenchus thornei under naturally infested field conditions in Turkey. Nematology, 21, 557-571. https://doi.org/10.1163/15685411-00003235

Dababat, A. A., Muminjanov, H., \& Smiley, R.W. (2015). Nematodes of Small Grain Cereals: Current Status and Research. FAO: Ankara, Turkey.

Dababat, A. A., Muminjanov, H., Erginbas-Orakci, G., Fakhraddin, G. A., Waeyenberge, L., Yildiz, Ş., \& Imren, M. (2019c). Distribution and diversity of cyst nematode (Nematoda: Heteroderidae) populations in the republic of Azerbaijan, and their molecular characterization using ITs-rDNA analysis. Nematropica, 49, 18-30.

Dababat, A. A. (2019). Resistance and tolerance reactions of winter wheat lines to Heterodera filipjevi in Turkey. Journal of nematology, 51, 1-12. https://doi.org/10.21307/jofnem-2019-031

Davies, K. G., de Leij, F. A. A. M., \& Kerry, B. R. (1991). Microbial agents for the biological control of plant-parasitic nematodes in tropical agriculture. Tropical Pest Management, 37, 303-320.

Dawabah, A. A. M., Al-Hazmi, A. S., \& Al-Yahya, F. A. (2015). Management of cereal cyst nematode (Heterodera avenae) in a large-scale wheat production. Nematodes of Small Grain Cereals, 277.

Dawabah, A. A. M., \& Al-Hazmi, A. S. (2007). Spreading of cereal cyst nematode with potato seed tubers in Saudi Arabia. Pakistan Journal of Nematology, 25, 339.

De Majnik, J., Ogbonnaya, F. C., Moullet, O., \& Lagudah, E. S. (2003). The Cre1 and Cre3 nematode resistance genes are located at homeologous loci in the wheat genome.
Molecular Plant-Microbe Interactions Journal, 16, 11291134. https://doi.org/10.1094/MPMI.2003.16.12.1129 Decraemer, W., \& Hunt, D. (2006). Structure and classification. In R. Perry \& M. Moens (Eds.). Plant nematology. Oxfordshire: $\quad \mathrm{CAB}$ International, 3-32. https://doi.org/10.1079/9781845930561.0000

Dubcovsky, J., \& Dvorak, J. (2007). Genome plasticity a key factor in the success of polyploid wheat under domestication. Science, 316, 1862-1866. https://doi.org/10.1126/science.1143986

Eagles, H. A., Bariana, H. S., Ogbonnaya, F. C., Rebetzke, G. J., \& Hollamby, G. J. (2001). Implementation of markers in Australian wheat breeding. Australian Journal of Agricultural Research, 52, 1349-1356. https://doi.org/10.1071/AR01067

Ellison F. W, Brown G. N., Mares D. J., Moore S. G., \& O'Brien L (1995) Registration of Australian winter cereal cultivars Triticum aestivum ssp. vulgare (bread wheat) cv. Sunvale. Australian Journal of Experimental Agriculture, 35, 416. https://doi.org/10.1071/EA9950416

Fard, H. K., Pourjam, E., \& Maaf, Z. T. (2015). Assessment of grain yield reduction caused by Heterodera filipjevi in wheat cultivars under normal irrigation and drought stress in natural field conditions. Nematodes of Small Grain Cereals, 115.

Fard, H. K., Pourjam, E., Maafi Z. T., \& Safaie, N. (2018). Assessment of yield loss of wheat cultivars caused by Heterodera filipjevi under field conditions. Journal of Phytopathology, 1, 1-6. https://doi.org/10.1111/jph.12686

Feldman, M., Levy, A. A., Fahima, T., \& Korol, A. (2012). Genomic asymmetry in allopolyploid plants: wheat as a model. Journal of Experimental Botany, 63(14), 5045-59. https://doi.org/10.1093/jxb/ers192

Food and Agriculture Organization of the United Nations, FAOSTAT statistics database. (2019). Crops. www.fao.org/faostat/en/\#data/QC

Franklin, M. T. (1969). Heterodera latipons n. sp., a cereal cyst nematode from the Mediterranean region. Nematologica, 15, 535-542.

Gantasala, N., Kumar, M., Banakar, P., Thakur, P., \& Rao, U. (2015). Functional validation of genes in cereal cyst nematode, Heterodera avenae, using siRNA gene silencing. In A. A. Dababat, H. Muminjanov \& R. Smiley (Eds). Nematodes of small grain cereals: current status and research. Ankara, Turkey: FAO, 353-356.

Gheysen, G., Van der Eycken, W., Barthels, N., Karimi, M., \& Van Montagu, M. (1996). The exploitation of nematoderesponsive plant genes in novel nematode control methods. Pesticide Science, 47, 95-101. https://doi.org/10.1002/(SICl)1096-9063

Gözel, U., \& Elekcioğlu, í. H. (2001). Research on plant parasitic nematodes found in wheat fields in the East Mediterranean Region. Institute of Science of Çukurova University, [Phd Thesis], Adana, Turkey.

Greco, N., Vovlas, N., Troccoli, A., \& Inserra, R. N. (2002). The Mediterranean cereal cyst nematode, Heterodera latipons: a menace to cool season cereals of the United States. Nematology Circular 221. (Florida Department of Agriculture and Conservation Services: Gainesville, Florida, USA).

Hajihasani, A., Tanha Maafi, Z., Nicol, J. M., \& Seraji, A. (2010a). Relationships between population densities of the cereal cyst nematode, Heterodera latipons and yield losses of 
winter wheat in microplots. Australasian Plant Pathology, 39(6): 530-535.

https://doi.org/10.1071/AP10132

Hajihassani, A., Tanha Maafi, Z., Nicol, J. M., \& Rezaee, S. (2010b). Effect of the cereal cyst nematode, Heterodera filipjevi, on wheat in microplot trials. Nematology, 12, 357- 363.

https://doi.org/10.1163/138855409X12548945788321

Hajihassani, A., Ebrahimian, E., \& Hajihasani, M. (2013). Estimation of yield damage in potato caused by Iranian population of Globodera rostochiensis with and without aldicarb under greenhouse conditions. International Journal of Agriculture and Biology, 15(2), 352-356.

Handa, D. K., \& Yadav, B. D. (1991). Comparative losses in husked, huskless barley and wheat due to Heterodera avenae in Rajasthan. Indian Journal of Nematology, 2, 99-102.

Hassan, G. A., Al-Assas, K., \& Jamal, M. (2010). Damage potential and reproduction of Heterodera avenae on wheat under Syrian field conditions. Nematologia Mediterranea, Cnr38, 73-78.

Holgado, R., Rowe, J., Andersson, S., \& Magnusson, C. (2004). Electrophoresis and biotest studies on some populations of cereal cyst nematode, Heterodera spp. (Tylenchida: Heteroderidae). Nematology, 6, 857-865. https://doi.org/10.1163/1568541044038551

Hollaway, G. J., Taylor, S. P., Eastwood, R. F., \& Hunt, C. H. (2000). Effect of field crops on density of Pratylenchus neglectus and $P$. thornei in southeastern Australia: Part 2. P. thornei. Journal of Nematology, 32(4S), 600-608.

Huang, X., Börner, A., Röder, M., \& Ganal, M. (2002). Assessing genetic diversity of wheat (Triticum aestivum L.) germplasm using microsatellite markers. Theoretical and Applied Genetics, 105, 699-707. https://doi.org/10.1007/s00122-002-0959-4

Husenov, B., Otambekova, M., Muminjanov, H., Morgounov, A., Asaad, S., Garkava-Gustavsson, L. \& Johansson, E. (2020). Constraints and Perspectives for Sustainable Wheat Production in Tajikistan. Front. Sustain. Food System, 4, 27. https://doi.org/10.3389/fsufs.2020.00027

Hussain, S., \& Rivandi, A. (2007). Molecular breeding for drought tolerance in plants: Wheat perspective. Proceedings of the Pakistan Academy of Sciences. 44, 3562.

Ibrahim, A., Al Hazmi, A. S., Al Yahya, F. A., \& Alderfasi, A. A. (1999). Damage potential and reproduction of Heterodera avenae on wheat and barley under Saudi field conditions. Nematology, 1, 625-630. https://doi.org/10.1163/156854199508577

Imren, M., Toktay, H., Bozbuga, R., Erginbas-Orakcl, G., Dababat, A. A., \& Elekcioglu, I. H. (2013). Identification of genetic resistance to cereal cyst nematodes; Heterodera avenae (Wollenweber, 1924), H. filipjevi (Madzhidov, 1981) Stelter and H. latipons (Franklin, 1969) in some international bread wheat germplasms. Turkish Journal of Entomology, 37, 277-282.

Imren, M., Toktay, H., Kütük, H., \& Dababat, A. A. (2016). Occurrence and identification of cereal cyst nematode, Heterodera filipjevi (Nemata: Heteroderidae), in Bolu Province of Turkey. Nematropica, 46, 154-161.

Imren, M., Waeyenberge, L., Koca, A. S., Duman, N., Yıldız, Ş., \& Dababat, A. A. (2017). Genetic variation and population dynamics of the cyst nematode, Heterodera filipjevi (Madzhidov) Stelter in wheat areas of Bolu,
Turkey. Tropical Plant Pathology, 42(3), 362-369. https://doi.org/10.1007/s40858-017-0160-6

Imren, M., Koca, A. S., \& Dababat, A. A. (2019). Identification of Heterodera latipons using PCR with sequence characterised amplified region (SCAR) primers. International Journal of Agriculture and Wildlife Science, 5(1), 90-95. https://doi.org/10.24180/ijaws.512967

Imren, M., Yildiz, Ş., Çiftçi, V., \& Dababat, A. A. (2020). Effect of cereal cyst nematode Heterodera filipjevi on wheat yields in Turkey. Turkish Journal of Agriculture and Forestry, 44, 39-45.

https://doi.org/10.3906/tar-1902-17

Jones, J. T., Haegeman, A., Danchin, E. G. J., Gaur, H. S., Helder, J., \& Jones, M. G. K. (2013). Top 10 plant-parasitic nematodes in molecular plant pathology. Physiological and Molecular Plant Pathology, 946-961. https://doi.org/10.1111/mpp.12057

Keetch, D. P. (1989). A perspective of plant nematology in South Africa. South African Journal of Science, 85, 506508.

Kretschmer, J. M., Chalmers, K. J., Manning, S., Karakousis, A., Barr, A. R., A. Islam, K. M. R., Logue, S. J., Choe, Y. W., Barker, S. J., Lance, R. C. M. \& Langridge, P. (1997). RFLP mapping of the Ha 2 cereal cyst nematode resistance gene in barley. Theoretical and Applied Genetics, 94, 1060-1064. https://doi.org/10.1007/s001220050515

Kühn, J. (1874). Über das vorkommen von rübennematoden and den wurzeln der halmfrüchte. Zeitschrift für wissenschaftliche Landwirthschaft und Archiv des Königlichen Preussischen Landes-Ökonomie-Kollegiums. 3, 47-50.

Kumar, V., \& Jain, M. (2015). The CRISPR-Cas system for plant genome editing: advances and opportunities. Journal of Experimental Botany, 66, 47-57. https://doi.org/10.1093/jxb/eru429

Liebscher, G. (1892). Beobachtungen über das Auftreten eines Nematoden an Erbsen. Journal für Landwirtschaft. 40, 357-368.

Luo, S., Liu, S., Kong, L., Peng, H., Huang, W., Jian, H., \& Peng, D. (2019). Two venom allergen-like proteins, HaVAP1 and HaVAP2, are involved in the parasitism of Heterodera avenae. Molecular Plant Pathology, 20(4), 471-484. https://doi.org/10.1111/mpp.12768

Madzhidov, A. R. (1981). Bidera filipjevi n. sp. (Heteroderina: Tylenchida) in Tadzhikistan. Nauk Izvestiya Akademii Nauk, 2, 40-44.

Maqbool, M. A. (1988). Present status of research on plantparasitic nematodes in cereals and food and forage legumes in Pakistan. In M. C. Saxena, R. A. Sikora \& J. P. Srivastava (Eds). Nematodes parasitic to cereals and legumes in temperate semi-arid regions, Aleppo: Workshop Proceedings, Larnaca, Cyprus, 1-5 March 1987. ICARDA, 173-180.

Mathur, B. N., Handa, D. K., Swaroop, S., Sethi, C. L., Sharma, G. L., \& Yadav, B. D. (1980). On the loss estimation and chemical control of molya disease of wheat caused by Heterodera avenae in India. Indian Journal of Nematology, 16, 152-159.

Matsuoka, Y. (2011). Evolution of polyploid Triticum wheat under cultivation: the role of domestication, natural hybridization and allopolyploid speciation in their diversification. Plant and Cell Physiology, 52(5), 750764. https://doi.org/10.1093/pcp/pcr018

Mayer, K. F. X., Rogers, J., Doleel, J., Pozniak, C., Eversole, K., \& Feuillet, C., et al. (2014). A chromosome-based draft 
sequence of the hexaploid bread wheat (Triticum aestivum) genome. Science, 345, 1251788-1251788. https://doi.org/10.1126/science.1251788

McDonald, A., \& Nicol, J. (2005). Nematode parasites of cereals. In M. Luc, R.A. Sikora \& J. Bridge (Eds). Plant parasitic nematodes in subtropical and tropical agriculture. Wallingford, U.K.: CAB Int., 131-191. https://doi.org/10.1079/9780851997278.0131

McFadden, E. S., \& Sears, E. R. (1946). The origin of Triticum spelta and its free-threshing hexaploid relatives. Journal of Heredity, 37, 107-116. https://doi.org/10.1093/oxfordjournals.jhered.a105590

Meagher, J. W. (1972). Cereal cyst nematode (Heterodera avenae Woll.). Studies on ecology and control in Victoria. Victorian Department of Agriculture Technical Bulletin, 24, 50p.

Misirlioglu, B., \& Pehlivan, E. (2007). Investigations on effects on plant growth and determination of plant parasitic nematodes found in wheat fields in the Aegean and Marmara Regions. Plant Protection Bulletin, 47, 13-29.

Mokabli, A., Valette, S., Gauthier, J. P., \& Rivoal, R. (2002). Variation in virulence of cereal cyst nematode populations from North Africa and Asia. Nematology, 4, 521-525.

https://doi.org/10.1163/156854102760290491

Mokrini, F., Viaene, N., Waeyenberge, L., Dababat, A. A., \& Moens, M. (2017). Characterization of cereal cyst nematodes (Heterodera spp.) in Morocco based on morphology, morphometrics and rDNA-ITS sequence analysis. Journal of Plant Protection Research, 57, 219227. https://doi.org/10.1515/jppr-2017-0031

Mokrini, F., Viaene, N., Waeyenberge, L., Dababat, A. A., \& Moens, M. (2018). Investigation of resistance to Pratylenchus penetrans and $P$. thornei in international wheat lines and its durability when inoculated together with the cereal cyst nematode Heterodera avenae, using qPCR for nematode quantification. European Journal of Plant Pathology, 151, 875-889.

https://doi.org/10.1007/s10658-018-1420-0

Mokrini, F., Waeyenberge, L., Viaene, N., Abbad Andaloussi, F., \& Moens, M. (2016). Diversity of root-lesion nematodes (Pratylenchus spp.) associated with wheat (Triticum aestivum and T. durum) in Morocco. Nematology, 18, 781-801. https://doi.org/10.1163/15685411-00002993

Mor, M., Cohn, E., \& Spiegel, Y. (1992). Phenology, pathogenicity and pathotypes of cereal cyst nematodes, Heterodera avenae and $H$. latipons (Nematoda: Heteroderidae) in Israel. Nematologica, 38, 494-501. https://doi.org/10.1163/187529292X00469

Mor, M., Spiegel, Y., \& Oka, Y. (2008). Histological study of syncytia induced in cereals by the Mediterranean cereal cyst nematode, Heterodera latipons. Nematology, 10, 279-287.

https://doi.org/10.1163/156854108783476340

Mulki, M. A., Jighly, A., Ye, G., Emebiri, L. C., \& Moody, D. (2013). Association mapping for soilborne pathogen resistance in synthetic hexaploid wheat. Molecular Breeding, 31, 299-311. https://doi.org/10.1007/s11032012-9790-z

Namouchi-Kachouri, N., B'chir, M. M., \& Hajji, A. (2007). Effect of initial populations of Heterodera avenae Woll. on wheat and barley yield components and on final nematode populations under Tunisian field conditions.

Tunisian Journal of Plant Protection, 3, 19-26. https:// doi.org/10.3906/tar-1312-91
Nicol, J., Davies, K. A., Hancock, T. W., \& Fisher, J. M. (2000). Yield loss caused by Pratylenchus thornei on wheat in South Australia. Journal of Nematology, 31(4), 367-76

Nicol, J., Elekçioğlu, H., Bolat, N., \& Rivoal, R. (2004). The global importance of the cereal cyst nematode (Heterodera spp.) on wheat and international approaches to its control. Communications in Agricultural and Applied Biological Sciences, 72, 677-686

Nicol, J., Rivoal, R., Taylor, S., \& Zaharieva, M. (2003). Global importance of cyst (Heterodera spp.) and lesion nematodes (Pratylenchus spp.) on cereals: Distribution, yield loss, use of host resistance and integration of molecular tools. Nematology Monographs and Perspectives, 2, 1-19.

Nicol, J., Turner, D., Coyne, L., den Nijs, L., Hockland, S., \& Maafi, Z. (2011). Current nematode threats to world agriculture. In J. Jones, G. Gheysen \& C. Fenoll (Eds). Genomics and molecular genetics of plant-nematode interactions. Berlin: Springer Science Business Media, 21-43. https://doi.org/10.1007/978-94-007-0434-3_2

Nicol, J. M. (2002). Important Nematode Pests of Cereals. In B. Curtis, S. Rajaram \& G. Macpherson (Eds). Bread wheat: improvement and production. Rome, Italy: FAO, 345366.

Nicol, J. M., \& Rivoal, R. (2008). Global Knowledge and its Application for the Integrated Control and Management of Nematodes on Wheat. In A. Ciancio \& K. G. Mukerji (Eds.). Integrated management and biocontrol of vegetable and grain crops nematodes. Springer, Dordrech, 251-294. https://doi.org/10.1007/978-14020-6063-2 13

Nicol, J. M., Bolat, N., Bagci, A., Trethowan, R. T., William, \& M., Hekimhan, H. (2007a). The International breeding strategy for the incorporation of resistance in bread wheat against the soil borne pathogens (dryland root rot and cyst and lesion cereal nematodes) using conventional and molecular tools. In H.T. Buck et al. (Eds.). Wheat production in stressed environments. Springer, Dordrecht, 125-137. https://doi.org/10.1007/1-4020-5497-1 17

Nicol, J. M., Bolat, N., Sahin, E., Tülek, A., Yıldırım, A. F., \& Yorgancilar, A. (2006). The cereal cyst nematode is causing economic damage on rain-fed wheat production systems of Turkey. Phytopathology, 96, S169.

Nicol, J. M., Davies, K. A., Hancock, T. W., \& Fisher, J. M. (1999). Yield loss caused by Pratylenchus thornei on wheat in South Australia. Journal of Nematology, 31, 367-376.

Nicol, J. M., Elekçioğlu, I. H., Bolat, N., \& Rivoal, R. (2007b). The global importance of the cereal cyst nematode (Heterodera spp.) on wheat and international approaches to its control. Communications in Agricultural and Applied Biological Sciences, 72, 677686.

Nicol, J. M., Rivoal, R., Trethowan, R. M., Van Ginkel, M., Mergoum, M., \& Singh, R. P. (2001). CIMMYT's approach to identify and use resistance to nematodes and soilborne fungi, in developing superior wheat germplasm. In: Z. Bedo \& L. Lang (Eds). Wheat in a global environment. Dordrecht, Kluwer Academic Publishers the Netherlands, 381-389. https://doi.org/10.1007/97894-017-3674-9 49

Nombela, G., \& Romero, M. D. (1999). Host response to Pratylenchus thornei of a wheat line carrying the Cre2 gene for resistance to Heterodera avenae. Nematology, 1, 381-388. https://doi.org/10.1163/156854199508379 
Ogbonnaya, F. C., Eastwood, R. F., \& Lagudah, E. (2009). Identification and utilisation of genes for cereal cyst nematode resistance (Heterodera avenae) resistance in wheat: the Australian experience. Cereal Cyst Nematodes, 166.

Ogbonnaya, F. C., Emebiri, L. C., Jilal, A., Trethowan, R., Abdalla, O., \& Brettell, R. (2008). Molecular diversity and association mapping in a collection of synthetic hexaploid wheat. Proceedings of the 11th International Wheat Genetics Symposium, Brisbane, Australia, 25-27.

Ogbonnaya, F. C., Seah, S., Delibes, A., Jahier, J., LópezBraña I., \& Eastwood R. F. (2001a). Molecular-genetic characterisation of a new nematode resistance gene in wheat. Theoretical and Applied Genetics, 102, 623- 629. https://doi.org/10.1007/s001220051689

Ogbonnaya, F. C., Subrahmanyam, N. C., Moullet, O., De Majnik, J., \& Eagles, H. A. (2001b). Diagnostic DNA markers for cereal cyst nematode resistance in bread wheat. Australian Journal of Agricultural Research, 52, 1367- 1374. https://doi.org/10.1071/AR01031

Oka, Y., Gözel, U., Spiegel, Y., \& Mor, M. (2009). Cereal Cyst Nematodes in Israel, and Their Biology and Control Strategies. In I. T. Riley, J. M. Nicol, \& A. A. Dababat (Eds). Cereal cyst nematodes: status, research and outlook, CIMMYT, Ankara, Turkey, 118-122.

Pariyar, S. R., Dababat, A. A., Sannemann, W., Erginbas-Orakci, G., Elashry, A., Siddique, S., Morgounov, A., Leon, J. \& Grundler, F. M. (2016a). Genome-wide association study in wheat identifies resistance to the cereal cyst nematode Heterodera filipjevi. Phytopathology, 106(10), 1128-1138. https://doi.org/10.1094/PHYTO-02-16-0054-FI

Pariyar, S. R., Dababat, A. A., Siddique, S., Erginbas-Orakci, G., Elashry, A., Morgounov, A., Leon, J., \& Grundler, F. M. W. (2016b). Identification and characterization of resistance to the cereal cyst nematode Heterodera filipjevi in winter wheat. Nematology, 18, 377-402. https://doi.org/10.1163/15685411-00002964

Peng, D., Nicol, J. M., Zhang, D., Chen, S., Waeyenberge, L., \& Moens, M. (2007). Occurrence, distribution and research situation of cereal cyst nematode in China. International Plant Protection Conference, Scotland, Glasgow.

Philis, I. (1988). Occurrence of Heterodera latipons on barley in Cyprus. Nematologia Mediterranea. 16, 223.

Philis, I. (1997). Heterodera latipons and Pratylenchus thornei attacking barley in Cyprus. Nematologia Mediterranea, 25, 305-309.

Piperno, D. R., Weiss, E., Holst, I., \& Nadel, D. (2004). Processing of wild cereal grains in the upper palaeolithic revealed by starch grain analysis. Nature, 430, 670-673. https://doi.org/10.1038/nature02734

Pourjam, E., Kheiri, A., Geraert, E., \& Alizadeh, A. (1999). Variations in Iranian populations of Pratylenchus neglectus and $P$. thornei (Nematoda: Pratylenchidae). Iranian Journal of Plant Physiology ,35, 23-27.

Renco, M., C`ermák, V., Tománková, K., \& C`udejková, M. M. (2018). Morphological and molecular characterisation of Heterodera filipjevi (Madzhidov, 1981) from the Slovak Republic. Nematology, 20, 253-264. https://doi.org/10.1163/15685411- 00003138

Riley, I. T., \& Qi, R. D. (2015). Annotated bibliography of cereal cyst nematodes (Heterodera avenae and $H$. filipjevi) in China, 1991 to 2014. Australasian Nematology Newsletter, 26, 1-46.

Rivoal, R., \& Cook, R. (1993). Nematode Pests of Cereals, in Plant Parasitic Nematodes. In K. Evans, D. Trudgill \& J.
Webster (Eds). Temperate agriculture, Wallingford, U.K.: CAB International, 259-303.

Rivoal, R., \& Sarr, E. (1987). Field experiments on Heterodera avenae in France and implications for winter wheat performance. Nematologica, 33(4), 460-479. https://doi.org/10.1163/187529287X00119

Rivoal, R., Bekal, S., Valette, S., Gauthier, J. P., \& Fradj, M. (2001). Variation in reproductive capacity and virulence on different genotypes and resistance genes of Triticeae, in the cereal cyst nematode species complex. Nematology, 3, 581-592. https://doi.org/10.1163/156854101753389194

Rivoal, R., Vallete, S., Bekal, S., Gauthier, J. P., \& Yahyaoui, A. (2003). Genetic and phenotypyic diversity in the graminaceous cyst nematode complex, inferred from PCR-RFLP of ribosomal DNA and morphometric analysis. https://doi.org/10.1023/A:1022838806268

Rumpenhorst, H. J., Elekçioğlu, I. H., Sturhan, D., Ozturk, G., \& Enneli, S. (1996). The cereal cyst nematode Heterodera filipjevi (Madzhidov) in Turkey. Nematologia Mediterranea 24, 135-138.

Sabova, M., Valocka, B., Liskova, M., \& Vargova, V. (1988). The first finding of Heterodera latipons Franklin,1969 on grass stands in Czechoslovakia. Helminthologia, 25, 201206.

Safari, E., Gororo, N. N., Eastwood, R. F., Lewis, J., Eagles, H. A., \& Ogbonnaya, F. C. (2005). Impact of Cre1, Cre 8 and Cre3 genes on cereal cyst nematode resistance in wheat. Theoretical and Applied Genetics, 110, 567-572. https://doi.org/10.1007/s00122-004-1873-8

Safferling, M. (2008). Spirotetramat: the first phloem-mobile and fully systemic insecticide. Bayer Crop Science, 61(2).

Sahin, E., Nicol, J. M., Yorgancilar, A., Elekcioglu, I. H., Tulek, A., \& Yildirim, A. F. (2008). Seasonal variation of field populations of Heterodera filipjevi, Pratylenchus thornei and $P$. neglectus on winter wheat in Turkey. Nematologia Mediterranea, 36, 51-56.

Schmidt, A. (1871). Über den Rüben-Nematoden (Heterodera schachtii A.S.) Zeitschrift des Vereines für die Rübenzucker- Industrie im Zollverein. 21, 1-19.

Schmidt, A. L, McIntyre, C. L., Thompson, J., Seymour, N. P., \& Liu, C.J. (2005). Quantitative trait loci for root lesion nematode (Pratylenchus thornei) resistance in Middle Eastern landraces and their potential for introgression into Australian bread wheat. Australian Journal of Agricultural Research, 56, 1059-1068. https://doi.org/10.1071/AR05016

Scholz, U. (2001). Biology, pathogenicity and control of the cereal cyst nematode Heterodera latipons Franklin on wheat and barley under semiarid conditions, and interactions with common root rot Bipolaris sorokiniana (Sacc.) Shoemaker [Teleomorph: Cochliobolus sativus (Ito et Kurib.) Drechs. ex Dastur.]. Bonn University, [Ph.D. thesis], Bonn, Germany.

Seid, A., Fininsa, C., Mekete, T., Decraemer, W., \& Wesemael, W. (2015). Tomato (Solanum lycopersicum) and rootknot nematodes (Meloidogyne spp.): a century-old battle. Nematology, 17(9), 995-1009. https://doi.org/10.1163/15685411-00002935

Sewell, R. (1973). Plant-parasitic nematodes from Canada and abroad. Canadian Plant Disease Survey, 53, 34-35.

Sheedy, J. G., \& Thompson, J. P. (2009). Resistance to the rootlesion nematode Pratylenchus thornei of Iranian landrace wheat. Australasian Plant Pathology, 38(5), 478-489. https://doi.org/10.1071/AP09030 
Sheedy, J. G., Smiley, R. W., Easley, S. A., \& Thompson, A. L. (2008). Resistance of Pacific Northwest spring wheat and barley cultivars to root-lesion nematode; Pratylenchus thornei. Plant Disease Management Reports, Vol 2. APS Press, St. Paul, MN.

Sheedy, J. G., Smiley, R. W., Easley, S. A., \& Thompson, A. L. (2007). Resistance reaction of Pacific Northwest spring wheat and barley cultivars to root-lesion nematode Pratylenchus neglectus. Plant Disease Management Reports, Vol 1. APS Press, St. Paul, MN.

Sher, S. A., \& Allen, M. W. (1953) Revision of the genus Pratylenchus (Nematoda: Tylenchida). University of California Publications in Zoology, 57, 441-470.

Shewry, P. R. (2009). Wheat. Journal of Experimental Botany, 60(6), 1537-1553. https://doi.org/10.1093/jxb/erp058

Shiferaw, B. Smale, M., Braun, H. J., Duveiller, E., Reynolds, M., \& Muricho, G. (2013). Crops that feed the world. Past successes and future challenges to the role played by wheat in global food security. Food Security 5, 291-317. https://doi.org/10.1007/s12571-013-0263-y

Sikora, R. A. (1988). Plant-parasitic nematodes of wheat and barley in temperate and temperate semi-arid regions a comparative analysis. In M. C. Saxena, R. A. Sikora \& J. P. Srivastava (Eds). Nematodes parasitic to cereals and legumes in temperate semi-arid regions, Aleppo: ICARDA, 46-48.

Sikora, R. A., \& Oostendorp, M. (1986). Report: Occurrence of plant-parasitic nematodes in ICARDA Experimental Fields. ICARDA, Aleppo, Syria.

Singh, A. K., Sharma, A. K., \& Shoran, J. (2009). Heterodera avenae and its management in India. In I. T. Riley, J. M. Nicol, \& A. A. Dababat (Eds). Cereal cyst nematodes: status, research and outlook, CIMMYT, Ankara, Turkey, 17-22.

Smiley, R. (2009). Occurrence, distribution and control of Heterodera avenae and $H$. filipjevi in the western USA. In I. T. Riley, J. M. Nicol, \& A. Dababat (Eds). Cereal cyst nematodes: status, research and outlook, Ankara, Turkey: CIMMYT, 35-40.

Smiley, R. W. (2010). Root-lesion nematodes: biology and management in Pacific Northwest wheat cropping systems. PNW Ext. Bull. 617, 9. https://doi.org/10.1146/annurev-phyto-080615100257

Smiley, R., \& Guiping, Y. (2010). Cereal cyst nematodes. Biology and management in Pacific Northwest wheat, barley, and oat crops. A Pacific Northwest Extension Publication Oregon State University [Internet] 2010. Retrieved $15 \quad$ April 2010 from http://ir.library.oregonstate.edu/xmlui/bitstream/handl e/1957/18917/pnw620.pdf

Smiley, R. W., \& Marshall, J. M. (2016). Detection of dual Heterodera avenae resistance plus tolerance traits in spring wheat. Plant Disease, 100, 1-23. https://doi.org/10.1094/PDIS-09-15- 1055- RE

Smiley, R. W., \& Nicol, J. M. (2009). Nematodes which challenge global wheat production. In B. F. Carver, \& I. A. Ames (Eds). Wheat science and trade. USA, WileyBlackwell.

Smiley, R. W., Gourlie, J. A., Rhinhart, K. E. L., Marshall, J. M., Anderson, M. D., \& Yan, G. P. (2012). Influence of nematicides and fungicides on spring wheat in fields infested with soilborne pathogens. Plant Disease, 96, 1537-1547.https://doi.org/10.1094/PDIS-02-12-0165RE

Smiley, R. W., Ingham, R. E., Uddin, W., \& Cook, G. H. (1994). Crop sequences for managing cereal cyst nematode and fungal pathogens of winter wheat. Plant Disease, 78, 1142-1149. https://doi.org/10.1094/PD-78-1142.

Smiley, R. W., Marshall, J. M., \& Yan, G. P. (2011). Effect of foliarly-applied spirotetramat on reproduction of Heterodera avenae on wheat roots. Plant Disease, 95, 983-989. https://doi.org/10.1094/PDIS-01-11-0017

Smiley, R. W., Dababat, A. A., Iqbal, S., Jones, M. G., Maafi, Z. T., \& Peng, D. (2017). Cereal cyst nematodes: A complex and destructive group of Heterodera species. Plant Disease, 101(10), 1692-1720.

https://doi.org/10.1094/PDIS-03-17-0355-FE

Smiley, R. W., Merrifield, K., Patterson, L. M., Whittaker, R. G., \& Gourlie, J. A. (2004). Nematodes in dryland field crops in the semiarid Pacific Northwest United States. Journal of Nematology, 36, 54- 68.

Smiley, R. W., Whittaker, R. G., Gourlie, J. A., \& Easley, S. A. (2005). Suppression of wheat growth and yield by Pratylenchus neglectus in the Pacific Northwest. Plant Disease, 89, 958-967. https://doi.org/10.1094/PD-89$\underline{0958}$

Smiley, R. W., Yan, G. P., \& Handoo, Z. A. (2008). First record of the cyst nematode Heterodera filipjevi on wheat in Oregon. Plant Disease, 92, 1136-1136. https://doi.org/10.1094/PDIS-92-7-1136B

Sogut, M. A., \& Devran, Z. (2011). Distribution and molecular identification of root-lesion nematodes in temperature fruit orchards of Turkey. Nematropica, 41, 91-98.

Stanton, J., \& Fisher, J. (1988). Factors of early growth associated with tolerance of wheat to Heterodera avenae. Nematologica, 34, 188-197.

Stanton, J., \& Stirling, G. (1997). Nematodes as plant parasites. In. F. Brown, \& H. J. Ogle (Eds). Plant pathogens and plant diseases, Rockvale Publications, Australia, 127-142.

Starr, J. L., Koenning, S. R., Kirkpatrick, T. L., Robinson, A. F., Roberts, P. A., \& Nichols, R. L. (2007). The future of nematode management in cotton. Journal of Nematology, 39, 283-294.

Stirling, G. R., Stanton, J. M., \& Marshall, J. W. (1992). The importance of plant-parasitic nematodes to Australian and New Zealand agriculture. Australasian Plant Pathology, 21, 104-115. https://doi.org/10.1071/APP9920104

Stone, L. E. W. (1961). Oats as a trap-crop for cereal root eelworm. Plant Pathology, 10, 164. https://doi.org/10.1111/j.1365-3059.1961.tb00144.x

Stoyanov, D. (1982). Cyst-forming nematodes on cereals in Bulgaria. EPPO Bulletin, 12, 341-344. https://doi.org/10.1111/j.1365-2338.1982.tb01813.x

Subbotin, S. A., Mundo-Ocampo, M., \& Baldwin, J.G. (2010a). Description and Diagnosis of Heterodera Species. In D. J. Hunt, \& R. N. Perry (Eds). Systematics of cyst nematodes (Nematoda: Heteroderinae), Part B, Brill: Leiden, 1-512.

Subbotin, S. A., Mundo-Ocampo, M., \& Baldwin, J. G. (2010b). Description and Diagnosis of Heterodera species. In D. J. Hunt, \& R. N. Perry (Eds). Systematics of cyst nematodes (Nematoda: Heteroderinae), Part A, Leiden: Brill, 7-349.

Subbotin, S. A., Rumpenhorst, H. J. \& Sturhan, D. (1996). Morphological and electrophoretic studies on populations of the Heterodera avenae complex from former USSR. Russian Journal of Nematology, 4, 29-39.

Taheri, Z. M., Maafi, Z. T., Nazari, K., Nezhad, K. Z., Rakhshandehroo, F., \& Dababat, A. A. (2019). Combined study on genetic diversity of wheat genotypes using SNP marker and phenotypic reaction to Heterodera filipjevi. Genetic Resources and Crop Evolution, 66, 1791-1811. https://doi.org/10.1007/s10722-019-00836-z 
Tanha Maafi, Z., Sturhan, D., Kheiri, A., \& Geraert, E. (2007). Species of the Heterodera avenae group (Nematoda: Heteroderidae) from Iran. Russian Journal of Nematology, 15, 49-58.

Taylor, M. J., Bandi, C., Hoerauf, A. M., \& Lazdins, J. (2000). Wolbachia bacteria of filarial nematodes: a target for control? Parasitology Today, 16(5), 179-180. https://doi.org/10.1016/S0169-4758(00)01661-6

Taylor, S. P., Vanstone, V. A., Ware, A. H., McKay, A. C., Szot, D., \& Russ, M. H. (1999). Measuring yield loss in cereals caused by root lesion nematodes (Pratylenchus neglectus and $P$. thornei) with and without nematicide. Australian Journal of Agricultural Research, 50(4), 617627. https://doi.org/10.1071/A98103

Thompson, J. P, Brennan, P. S., Clewett, T. G., Sheedy, J. G., \& Seymour, N. P. (1999). Progress in breeding wheat for tolerance and resistance to root-lesion nematode (Pratylenchus thornei). Australian Journal of Agricultural Research, 28, 45- 52. https://doi.org/10.1071/AP99006

Thompson, J. P., \& Haak, M. I. (1997). Resistance to root-lesion nematode (Pratylenchus thornei) in Aegilops tauschii Coss., the D-genome donor to wheat. Australian Journal of Agricultural Research, 48, 553-559. https://doi.org/10.1071/A96167

Thompson, J. P., Clewett, T. G., Sheedy, J. G., Reen, R. A., O'Reilly, M. M., \& Bell, K. L. (2010). Occurrence of rootlesion nematodes (Pratylenchus thornei and $P$. neglectus) and stunt nematode (Merlinius brevidens) in the northern grain region of Australia. Australian Journal of Agricultural Research, 39(3), 254-264. https://doi.org/10.1071/AP09094

Thompson, J. P., Mackenzie, J., \& Amos, R. (1995). Root-lesion nematode (Pratylenchus thornei) limits response of wheat but not barley to stored soil moisture in the Hermitage long-term tillage experiment. Australian Journal of Agricultural Research, 35, 1049-1055. https://doi.org/10.1071/EA9951049

Thompson, J. P., \& Clewett, T. G. (1986). Research on root lesion nematode: Occurrence and wheat varietal reaction. Queensland Wheat Research Institute Biennial Report, 32-35.

Thompson, J. P., O'reilly, M. M., \& Clewett, T. G. (2009). Resistance to the root-lesion nematode Pratylenchus thornei in wheat landraces and cultivars from the West Asia and North Africa (WANA) region. Crop and Pasture Science, 60 (12), 1209-1217. https://doi.org/10.1071/CP09159

Thompson, J. P., Owen, K. J, Stirling, G. R., \& Bell, M. J. (2008). Root-lesion nematodes (Pratylenchus thornei and $P$. neglectus): a review of recent progress in managing a significant pest of grain crops in northern Australia. Australasian Plant Pathology, 37(3), 235-242.

Thompson, J. P., Rostad, R. H., \& Whish, J. P. M. (2016). Survival of root-lesion nematodes (Pratylenchus thornei) after wheat growth in a vertisol is influenced by rate of progressive soil desiccation. Annals of Applied Biology, 170, 78-88.

Tian, B., Yang, J., \& Zhang, K. (2007). Bacteria used in the biological control of plant-parasitic nematodes: populations, mechanisms of action, and future prospects. FEMS Microbial Ecology, 61, 197-213. https://doi.org/10.1111/j.1574-6941.2007.00349.x

Toktay, H., Mc Intyre, C. L., Nicol, J. M., Ozkan, H., \& Elekçioğlu, H. i. (2006). Identification of common root-lesion nematode (Pratylenchus thornei Sher et Allen) loci in bread wheat. Genome, 49,1319-1323. https://doi.org/10.1139/g06-090

Toktay, H. (2008). Resistance of some spring wheat against Pratylenchus thornei Sher et Allen Tylenchida: Pratylenchidae. Institute of Nature of Science of University of Cukurova, [PhD Thesis], Adana, Turkey.

Toktay, H., Yavuzaslanoğlu, E., İmren, M., Nicol, J., Elekcioğlu, i. H., \& Dababat, A. A. (2012). Screening for resistance to Heterodera filipjevi (Madzhidov) Stelter (Tylenchida: Heteroderidae) and Pratylenchus thornei (Sher \& Allen) (Tylenchida: Pratylenchidae) sister lines of spring wheat. Turkish Journal of Entomology, 36, 455-461.

Toumi, F., Waeyenberge, L., Viaene, N., Dababat, A. A., Nicol, J. M., Ogbonnaya, F., \& Moens, M. (2013). Development of a species-specific PCR to detect the cereal cyst nematode, Heterodera latipons. Nematology, 15, 709717. https://doi.org/10.1163/15685411-00002713

Toumi, F., Waeyenberge, L., Viaene, N., Dababat, A. A., Nicol, J. M., Ogbonnaya, F., \& Moens, M. (2017). Cereal cyst nematodes: importance, distribution, identification, quantification, and control. European Journal of Plant Pathology, 150, 1-20. https://doi.org/10.1007/s10658017-1263-0

Tripathi, L., Babirye, A., Roderick, H., Tripathi, J. N., Changa, C., \& Urwin, P. E. (2015). Field resistance of transgenic plantain to nematodes has potential for future African Food Security. Scientific Reports, 5, 8127. https://doi.org/10.1038/srep08127

Trudgill, D. (1991). Resistance to and tolerance of plant parasitic nematodes in plants. Annual Review of Phytopathology, 29, 167-192. https://doi.org/10.1146/annurev.py.29.090191.001123

Tulek, A., Kepenekci, I., Cifticigil, T. H., Ozturk, I., Akin, K., Seidi, M., Yildirim, M., \& Dababat, A. A. (2015). Effects of seedgall nematode, Anguina tritici, on bread wheat grain characteristics and yields in Turkey. Nematology, 17, 1099-1104. https://doi.org/10.1163/15685411-00002926

Vanstone, V. A., Hollaway, G. J., \& Stirling, G. R. (2008). Managing nematode pests in the southern and western regions of the Australian cereal industry: continuing progress in a challenging environment. Australasian Plant Pathology, 37, 220-234. https://doi.org/10.1071/AP08020

Vanstone, V. A., Rathjen, A. J., Ware, A. H., \& Wheeler, R. D. (1998). Relationship between root lesion nematodes (Pratylenchus neglectus and $P$. thornei) and performance of wheat varieties. Australian Journal of Experimental Agriculture, 38, 181-188. https://doi.org/10.1071/ea97109

Vishnudasan, D., Tripathi, M. N., Rao, U., \& Khurana, P. (2005). Assessment of nematode resistance in wheat transgenic plants expressing potato proteinase inhibitor (PIN2) gene. Translational Research, 14, 665-675. https://doi:.org/10.1007/s11248-005-5696-4

Volkmar, K. (1990). The cereal cyst nematode (Heterodera avenae) on oats. I. Identification of attributes useful in early screening for tolerance to $H$. avenae. Australian Journal of Agricultural Research, 41, 39-49. https://doi.org/10.1071/AR9900039

Wen, N., Thompson, Y. M., Campbell, K. G., \& Paulitz, T. (2019). Distribution of cereal cyst nematodes (Heterodera avenae and $H$. filipjevi) in Eastern Washington State. Plant Disease, 103, 2171-2178. https://doi.org/10.1094/PDIS-10-18-1881-SR

Whitehead, A. (1998). Plant nematode control, Volume VIII. CAB International: Oxon, UK; New York, NY, USA, 
Williams, K. J., Taylor, S. P., Bogacki, P., Pallotta, M., \& Bariana, H. S. et al. (2002). Mapping of the root lesion nematode (Pratylenchus neglectus) resistance gene RInn1 in wheat. Theoretical and Applied Genetics, 104, 874-879. https://doi.org/10.1007/s00122-001-0839-3

Wilson, R. E., Hollamby, G. J., \& Bayraktar, A. (1983). Selecting for high yield potential in wheat with tolerance to cereal cyst nematode. Aust. Field. Crops. Newsl. 18, 21-25.

Wollenweber, H. W. (1923). Krankheiten und Beschädigungen der Kartoffel. Arbeiten des Forschungsinstitutes für Kartoffelbau, 7, 52.

Wollenweber, H. W. (1924). Zur Kenntnis der KartoffelHeteroderen. Illustrierte Landwirtschaftliche Zeitung, 44, 100-101.

Wouts, W. W., Schoemaker, A., Sturhan, D., \& Burrows, P. R. (1995). Heterodera spinicauda sp. n. (Nematoda: Heteroderidae) from mud flats in the Netherlands, with a key to the species of the H. avenae group. Nematology, 41,575-583.

https://doi.org/10.1163/003925995X00512

Yu, Y., Liu, H., Zhu, A., Zhang, G., Zeng, L., \& Xue, S. (2012). A review of root lesion nematode: identification and plant resistance. Advances in Microbiology, 2(4), 411-416. https://doi.org/10.4236/aim.2012.24052

Yüksel, H. S. (1973). Studies on the morphological and biological differences of Heterodera species (Nematoda: Heteroderidae) in Turkey. Atatürk University Journal of
Agricultural Faculty, 4, 15-20.

Yousef, D. M., \& Jacob, J. J. (1994). A nematode survey of vegetable crops and some orchards in the Ghor of Jordan. Nematologia Mediterranea 22, 11-15.

Zhang, H., Song, Q., Griffin, J. D., \& Song, B. H. (2017). Genetic architecture of wild soybean (Glycine soja) response to soybean cyst nematode (Heterodera glycines). Molecular Genetics and Genomics, 292(6), 1257-1265. https://doi.org/10.1007/s00438-017-1345-X

Zwart, R. S., Thompson, J. P., \& Godwin, I. D. (2004). Genetic analysis of resistance to root-lesion nematode (Pratylenchus thornei) in wheat. Plant Breeding, 123, 209-212. $\quad$ https://doi.org/10.1111/j.14390523.2004.00986.x

Zwart, R. S., Thompson, J. P., \& Godwin, I. D. (2005). Identification of quantitative trait loci for resistance to two species of root-lesion nematode (Pratylenchus thornei and $P$. neglectus) in wheat. Australian Journal of Agricultural Research, 56, 345-352. https://doi.org/10.1071/AR04223

Zwart, R. S., Thompson, J. P., Sheedy, J. G., \& Nelson, J. C. (2006). Mapping quantitative trait loci for resistance to Pratylenchus thornei from synthetic hexaploid wheat in the International Triticeae Mapping Initiative (ITMI) population. Australian Journal of Agricultural Research, 57, 525-530. https://doi.org/10.1071/AR05177 